\title{
A novel model to explain dietary factors affecting hypocalcaemia in dairy cattle
}

\author{
Javier Martín-Tereso ${ }^{1 *}$ and Martin W. A. Verstegen ${ }^{2}$ \\ ${ }^{1}$ Nutreco Research and Development, Boxmeer, The Netherlands \\ ${ }^{2}$ Wageningen Institute of Animal Sciences, Wageningen University and Research Centre, The Netherlands
}

\begin{abstract}
Most dairy cows exhibit different degrees of hypocalcaemia around calving because the gestational Ca requirements shift to the disproportionately high $\mathrm{Ca}$ requirements of lactation. Ca homeostasis is a robust system that effectively adapts to changes in Ca demand or supply. However, these adaptations often are not rapid enough to avoid hypocalcaemia. A delay in the reconfiguration of intestinal Ca absorption and bone resorption is probably the underlying cause of this transient hypocalcaemia. Several dietary factors that affect different aspects of Ca metabolism are known to reduce the incidence of milk fever. The present review describes the interactions between nutrition and Ca homeostasis using observations from cattle and extrapolations from other species and aims to quantitatively model the effects of the nutritional approaches that are used to induce dry cows into an early adaptation of Ca metabolism. The present model suggests that reducing dietary cation-anion difference (DCAD) increases Ca clearance from the blood by dietary induction of systemic acidosis, which results in hypercalciuria due to the loss of function of the renal Ca transient receptor potential vanilloid channel TRPV5. Alternatively, reducing the gastrointestinal availability of $\mathrm{Ca}$ by reducing dietary $\mathrm{Ca}$ or its nutritional availability will also induce the activation of $\mathrm{Ca}$ metabolism to compensate for basal blood Ca clearance. Our model of gastrointestinal Ca availability as well as blood Ca clearance in the transition dairy cow allowed us to conclude that the most common dietary strategies for milk fever prevention may have analogous modes of action that are based on the principle of metabolic adaptation before calving.
\end{abstract}

Key words: Hypocalcaemia: Calcium homeostasis: Milk fever: Calving: Dietary cation-anion difference

\section{Introduction}

\section{Teleological background of milk fever}

Modern dairy cattle have a milk yield potential that greatly exceeds the nutritional needs of their offspring in quantities that can feed many more calves than the one or two they can bear. Under normal conditions, placental Ca transfer before calving is similar to $\mathrm{Ca}$ clearance into milk at the start of lactation ${ }^{(1)}$. This is the case in beef cows but not in modern dairy cows, in which the Ca yield in milk greatly exceeds the needs of a newborn calf. Consequently, calving represents a great challenge for $\mathrm{Ca}$ metabolism, which requires rapid adaptations to sustain Ca homeostasis.

Cows were part of the first group of domesticated species 10000 years ago ${ }^{(2)}$, and dairy breeds have existed for centuries. Much more recently, the intensification of dairy production brought cows into even closer symbiosis with man, which promoted the selection of certain genotypes. Consequently, diseases such as milk fever and ketosis, which are specific to dairy breeds, have been induced by this process. The milk production capacity in dairy cows has been largely increased by genetic improvement, but the robust physiology required to sustain production may be lagging behind. Involuntary culling of high-producing cows increases as the production system intensifies $^{(3-5)}$. High milk yield is positively related to disease incidence ${ }^{(6)}$, and negative genetic correlations have been calculated between milk production traits and disease resistance ${ }^{(7)}$. Nevertheless, these correlations are not necessarily causal because the intensification of dairy production includes many potential confounding factors, such as increased herd sizes and changes in farm management and feeding practices. While disease greatly increases involuntary culling, a high milk yield prevents voluntary culling ${ }^{(8)}$. Therefore, the limited longevity of modern dairy cows cannot be considered an unequivocal consequence of their extremely high productivity.

Darwin $^{(9)}$ defined evolution under domestication as the cumulative result of two different means of selection,

Abbreviations: DCAD, dietary cation-anion difference; DMI, DM intake; GI, gastrointestinally; PTH, parathyroid hormone; TRPV, transient receptor potential vanilloid.

*Corresponding author: Dr Javier Martín-Tereso, fax +31 485568 183, email javier.martin-tereso@nutreco.com 
'methodical selection' and 'unconscious selection'. 'Methodical selection' induces changes much faster than 'unconscious selection'. This principle may apply to dairy cows because modern genetic improvement has increased milk production within decades. Additionally, the high involuntary culling rates are a powerful means of 'unconscious selection' driven by insufficient disease resistance. If Darwin's intuition proves true, these means of selection will not soon provide a solution to this problem.

The mismatch between milk yield and disease resistance seems most dramatic in older cows because they reach maximum production. As cows age, they become more prone to ketosis ${ }^{(10)}$ and milk fever; specifically, there is a $9 \%$ increase in the incidence of milk fever with each lactation $^{(11)}$. Multiparous cows have a greater disparity in their nutrient intakes and yields at their lactation peaks compared with first parity cows. This disparity is most evident in the greater fluctuation in body condition scores during the production cycle ${ }^{(12)}$. Therefore, older cows experience a greater physiological adaptation of energy and mineral metabolism at the onset of lactation. The failure to adapt energy metabolism after calving results in ketosis. Similarly, the failure to adapt Ca metabolism can result in milk fever. Production diseases and infertility associated with the transition period result from an ineffective homeorhetic adaptation to the new physiological state ${ }^{(11)}$. Among the many homeorhetic changes in nutrient partitioning during the transition between gestation and lactation ${ }^{(13)}$, adaptations in $\mathrm{Ca}$ metabolism seem to be especially critical. These dynamic adaptations should be coordinated without breaking the inflexible requirement of $\mathrm{Ca}$ homeostasis in the blood, which is the main junction of Ca partitioning.

The lifespan of dairy cows has declined in the last few decades. Only $40 \%$ of dairy cows live beyond two lactations, and very few reach the eighth lactation ${ }^{(3)}$. Currently almost all dairy cows are younger than one-third of the maximum lifespan of bovine species, which is estimated to be 30 years $^{(14)}$. Therefore, the greater incidence of production diseases with increased parity is unlikely to be caused by ageing. Failure to adapt to the shifts in nutrient partitioning at calving, which becomes greater with age, may be a more plausible hypothesis to explain the increase in metabolic problems with increased parity.

Dairy nutritionists aim to facilitate the metabolic adaptations that occur around calving to prevent these health disorders. The final goal is to maintain animal welfare to consequently reduce replacement rates. This will improve the economic profitability and environmental footprint of dairy production ${ }^{(15)}$.

\section{Definition of milk fever}

Most cows have some degree of hypocalcaemia at calving; therefore, it is difficult to define milk fever as a discrete parameter. Serum Ca at calving drops below $2.0 \mathrm{~mm}$ in
$25 \%$ of heifers, $41 \%$ in second lactation cows and up to $54 \%$ in fifth lactation cows ${ }^{(16)}$. It is generally accepted that cows requiring treatment are considered to be clinical cases of milk fever, although this definition remains subjective. Periparturient subclinical or clinical hypocalcaemia as discrete observations are imprecisely defined, but arbitrary boundaries of 2.0 and $1.4 \mathrm{~mm}$ have been proposed for serum $\mathrm{Ca}^{(17)}$. Serum $\mathrm{Ca}$ is, however, a continuous parameter that can objectively be measured.

Ca homeostasis seldom fails under natural conditions. Dairy cows around the time of calving represent an exception to this rule. Hypocalcaemia occurs within a few days of calving but does not persist despite the increased Ca demand during early lactation. The cause of hypocalcaemia is therefore a delayed response of the adaptive mechanisms of $\mathrm{Ca}$ metabolism that eventually restore homeostasis.

\section{Calcium homeostasis}

\section{General definition}

Evolution has provided elaborate mechanisms for the physiological control of $\mathrm{Ca}$. At the cellular level, the concentration of ionic $\mathrm{Ca}$ in the cytoplasm remains several-fold below that of the extracellular environment. This is accomplished via regulation by membrane channels and complexation with proteins ${ }^{(18)}$. With the development of higher forms of life, an accurate control of Ca remained a high priority. Animals benefit from the precise homeostasis of blood Ca because positive or negative fluctuations can have fatal consequences. At the animal level, hormonal signals direct several Ca control mechanisms in different tissues. Transepithelial transport in the kidneys and intestine are the most important of these mechanisms ${ }^{(19)}$. Ca control is necessary to preserve vital functions, such as signalling and muscle contraction, the management of $\mathrm{Ca}$ reserves and the structural function of $\mathrm{Ca}$ in the bones.

Any change in influx or clearance of $\mathrm{Ca}$ in the blood challenges the homeostatic system. Positive fluctuations are naturally possible with high $\mathrm{Ca}$ intake, which results in increased, non-regulated, passive absorption. In this situation, the inflow would be quantitatively moderate. Ca infusions as a treatment for milk fever would be a non-physiological but extreme example of a positive fluctuation in blood Ca. Negative fluctuations are caused by increased clearance rates of $\mathrm{Ca}$ from the blood. This fluctuation, for example, occurs at the start of the lactation in the dairy cow or during hypercalciuria induced by metabolic acidosis.

The main framework of the hormonal system that controls Ca homeostasis in animals is well known. This system is mainly controlled by the coordinated action of parathyroid hormone (PTH) and calcitriol. This is also applicable to cattle ${ }^{(11,20,21)}$, although not all evidence 
can be extrapolated from the most extensively studied single-stomached species. The points of similarity and the divergences between homeostatic control in ruminant and single-stomached species have been extensively reviewed by Schröder \& Breves ${ }^{(22)}$. Controversy remains about the role of ruminal $\mathrm{Ca}$ absorption in the homeostatic system. Active ruminal absorption of Ca has been demonstrated in vitro ${ }^{(23)}$; however, in vivo validation ${ }^{(24)}$ and the quantification of the significance of this effect ${ }^{(25)}$ have not consistently been confirmed in ruminants. The latest data from goats suggest that active $\mathrm{Ca}$ absorption can occur simultaneously in the rumen and the intestine ${ }^{(26)}$. Hence, the role in $\mathrm{Ca}$ regulation of the postruminal gastrointestinal segments, and by extension, in the overall gastrointestinal tract is assumed to be comparable with that of singlestomached species.

The $\mathrm{Ca}^{2+}$ sensing receptor in the parathyroid gland monitors blood $\mathrm{Ca}^{(27)}$. This receptor was first identified in bovine parathyroid tissue two decades ago ${ }^{(28)}$. The parathyroid will respond to a decrease in blood Ca by releasing PTH. This signal sustains the extensive recovery of $\mathrm{Ca}$ in the kidney, and its absence allows for increased urinary $\mathrm{Ca}$ excretion to compensate for positive fluctuations in blood $\mathrm{Ca}^{(29)}$. On the contrary, an increase in PTH can slightly increase renal reabsorption, which is already high, in response to the negative fluctuations in blood Ca. This reaction occurs within hours after its secretion ${ }^{(30)}$, but because urinary $\mathrm{Ca}$ is naturally low, the value of this action against hypocalcaemia is quantitatively limited. Additionally, PTH will act against hypocalcaemia by initiating bone $\mathrm{Ca}$ mobilisation and by inducing the hydroxylation of 25-hydroxyvitamin $\mathrm{D}$ to calcitriol (1,25-dihydroxyvitamin D) in the kidney. Calcitriol activates $\mathrm{Ca}$ absorption in the gastrointestinal tract, which represents a large $\mathrm{Ca}$ resource to compensate for $\mathrm{Ca}$ clearance. In rats, this adaptation has been proven to take longer than $1 \mathrm{~d}$ to take effect ${ }^{(31)}$. To our knowledge, this delay has not been directly observed in cattle; however, we have observed indirect indications of this delay by monitoring urinary $\mathrm{Ca}$ in cows, which suggest that the inactivation of gastrointestinal $\mathrm{Ca}$ absorption may present a 2 d delay ${ }^{(29,32)}$. Furthermore, calcitriol sustains bone $\mathrm{Ca}$ mobilisation, offering an extensive pool for sustaining $\mathrm{Ca}$ homeostasis during lactation ${ }^{(33)}$; however, in the short term, the readily available bone $\mathrm{Ca}$ is limited ${ }^{(34)}$. Calcitriol only sustains bone mobilisation if the PTH signal is maintained. This happens only when gastrointestinal absorption is insufficient to compensate for the $\mathrm{Ca}$ deficit $^{(35)}$. Consequently, this mechanism prioritises dietary $\mathrm{Ca}$ above bone $\mathrm{Ca}$ in the compensation of blood $\mathrm{Ca}$ levels.

Dairy cows constantly need to adapt their Ca metabolism during their reproductive cycle. During early lactation, Ca from bone is mobilised because dietary $\mathrm{Ca}$ is insufficient for the high amounts of $\mathrm{Ca}$ required for milk production, regardless of very efficient active gastrointestinal $\mathrm{Ca}$ absorption. At a certain point in lactation, dietary $\mathrm{Ca}$ should suffice for the milk yield, but high intestinal absorption is maintained for several months to replenish bone reserves. In late lactation and the dry period, passive absorption is sufficient to compensate for low levels of blood Ca clearance, consisting of small faecal and urinary loses and fetal needs. This metabolic state suddenly changes to active absorption and bone mobilisation at calving, which requires very rapid adaptation to avoid hypocalcaemia. To understand the aetiology of milk fever, it is necessary to study the nature of these adaptive mechanisms and their ability to respond to the challenge of calving.

\section{Adaptive mechanisms of calcium homeostasis}

Practical animal nutrition often considers nutrient absorption to be a constant competence; however, Ca absorption is constantly changing due to endogenous signals and external stimuli from the diet. Many examples of these adaptations are known ${ }^{(36)}$. Ca homeostasis has been described by Ramberg et al. ${ }^{(1)}$ as a system with 'controlled signals, disturbing signals and controlling signals'. This approach suggests that the cause of milk fever could be a delay in the adaptive mechanisms ('controlling signals') that cannot provide timely responses to the sudden changes in $\mathrm{Ca}$ clearance from the blood. These adaptive mechanisms involve renal reabsorption, gastrointestinal absorption and bone turnover. These mechanisms are now much better understood thanks to new molecular techniques that have become available in the last few decades $^{(37)}$; data specific to ruminant species are beginning to emerge $^{(24,38,39)}$. Renal reabsorption and intestinal absorption are both tightly regulated processes of transepithelial $\mathrm{Ca}$ transport. Bone turnover is a tissue modification process that is regulated in such a way that it can respond anabolically or catabolically to sustain $\mathrm{Ca}$ homeostasis while maintaining the structural function of bone.

Transepithelial transport processes. Passive, non-saturable Ca diffusion occurs through the tight junctions of epithelia when $\mathrm{Ca}$ gradients allow for this paracellular transport. This mechanism can be regulated in the intestine of single-stomached species by modifying epithelial permeability ${ }^{(40,41)}$. Nevertheless, the transcellular, saturable $\mathrm{Ca}$ transport processes are subject to greater regulation and thus play a prominent role in Ca homeostasis.

Ca reabsorption in the kidney and active gastrointestinal absorption are transcellular processes that are coordinated by the hormonal $\mathrm{Ca}$ homeostatic system and that transport $\mathrm{Ca}$ against the concentration gradient into the blood. Transcellular epithelial transport of Ca consists of the following three steps: facilitated entry into epithelial cells, intracellular diffusion mediated by a binding protein and active transport from the cell into the next extracellular compartment ${ }^{(37)}$. Such an elaborate system allows for efficient and accurately controlled $\mathrm{Ca}$ transport while maintaining free intracellular $\mathrm{Ca}$ at a minimum. 
Ca enters the epithelial cells through two highly specific Ca channels; these transient receptor potential vanilloid (TRPV) channels are TRPV5 (formerly known as ECaC1 or CaT2) and TRPV6 (formerly known as ECaC2 or CaT1). Ca entry, although a passive transfer, is believed to represent the limiting, key regulatory step of the process and is strongly regulated by calcitriol ${ }^{(42)}$ and extracellular Ca concentration ${ }^{(43)}$.

Once inside the epithelial cell, Ca diffuses through the cytoplasm. Luminal Ca concentration is kept extremely low to protect normal cell function. At a low concentration, simple diffusion cannot quantitatively provide the requirements of Ca transfer in the intestine or kidney. Two cytosolic Ca-binding proteins, calbindin- $\mathrm{D}_{9 \mathrm{k}}$ and calbindin- $\mathrm{D}_{28 \mathrm{k}}$, have been described ${ }^{(37)}$. These proteins are calcitrioldependent and are responsible for ionic Ca buffering in the cell and facilitating intracellular diffusion in transepithelial transport ${ }^{(44)}$. This step can limit transport across the cell because the lack of calbindin proteins impedes Ca transport ${ }^{(44)}$.

The final step in transcellular transport is Ca export out of the cell into the bloodstream. This process is mediated by ATP via the following two active $\mathrm{Ca}$ transporters: the Ca-ATPase protein, also called plasma membrane $\mathrm{Ca}^{2+}$ ATPase (PMCA), and the $\mathrm{Na}^{+} / \mathrm{Ca}^{2+}$ exchanger $(\mathrm{NCX})^{(42)}$. This step is also regulated by calcitriol $^{(37)}$. However, this step is unlikely to be rate limiting ${ }^{(44)}$, which reduces its importance in the control of transcellular Ca transport.

Despite overall similarities, there are specific differences between intestine and kidney in the transport of Ca across the epithelium. These differences enable their distinct roles in Ca homeostasis while other differences are derived from the distinct nature of these tissues. There are molecular differences between renal and intestinal transcellular $\mathrm{Ca}$ transport. The main Ca entry channel in the intestine is TRPV6 ${ }^{(27)}$, whereas TRPV5 is the only known entry channel in the kidney ${ }^{(45)}$. In mammals, the predominant intracellular Ca-binding protein is calbindin- $\mathrm{D}_{28 \mathrm{k}}$ in the kidney and calbindin- $\mathrm{D}_{9 \mathrm{k}}$ in the intestine ${ }^{(42)}$. It is understood that PTH predominantly controls renal $\mathrm{Ca}$ reabsorption and that calcitriol plays a similar role in the intestinal system ${ }^{(22)}$. Vitamin D receptors are present in both tissues ${ }^{(38)}$. Additionally, PTH can directly affect renal and intestinal transport processes ${ }^{(37)}$.

These tissues differ in the specific regulation of the three steps of transepithelial transport because they respond differently to $\mathrm{Ca}$ hormones and $\mathrm{Ca}$ concentration in the compartments. In rats, the response of calbindin- $\mathrm{D}_{28 \mathrm{k}}$ in the kidney and calbindin- $\mathrm{D}_{9 \mathrm{k}}$ in the intestine to calcitriol differs in speed and intensity ${ }^{(31)}$. This same study described the age-dependent relationship of calbindin- $\mathrm{D}_{9 \mathrm{k}}$ expression. The responsiveness of calbindin- $\mathrm{D}_{9 \mathrm{k}}$ to calcitriol was not confirmed in the bovine intestine ${ }^{(39)}$ or bovine rumen ${ }^{(46)}$, but more recent data report calbindin- $\mathrm{D}_{9 \mathrm{k}}$ responses to calcitriol in the duodenum and rumen of goats ${ }^{(26)}$. Ca channels also present differences in regulation. The structural differences between TRPV5 and TRPV6 result in different down-regulation kinetics induced by $\mathrm{Ca}^{(43)}$, which translates into further differences between renal and intestinal $\mathrm{Ca}$ transport.

The functions and tissue specificity of the two mentioned Ca-binding proteins are not universal across the animal kingdom. Calbindin- $\mathrm{D}_{9 \mathrm{k}}$ is the $\mathrm{Ca}$-binding protein in the intestine, and calbindin- $\mathrm{D}_{28 \mathrm{k}}$ is the renal Ca-binding protein in all mammals, including bovines. In contrast, calbindin- $\mathrm{D}_{28 \mathrm{k}}$ is the intestinal and renal Ca-binding protein in birds ${ }^{(47)}$. The function of transepithelial Ca channels is well preserved across animal species. Therefore, bovine species appear to share the main framework of transepithelial $\mathrm{Ca}$ transport with mice and man in intestinal and renal tissue, thus allowing careful extrapolation from the data generated within these species.

A specific characteristic of TRPV5 is its $\mathrm{pH}$ sensitivity. TRPV5 has approximately half of its normal activity during metabolic acidosis ${ }^{(27)}$. This inhibition results in hypercalciuria, a common condition in cattle that are fed low-dietary cation-anion difference (DCAD) diets ${ }^{(48,49)}$ TRPV5 failure has been studied in TRPV5 gene knock-out mice. These animals combine the expected hypercalciuria with the hyperactivation of intestinal $\mathrm{Ca}$ absorption and present high circulating calcitriol levels and increased TRPV6 expression ${ }^{(50)}$.

Prevention of milk fever with low-DCAD diets has been clearly demonstrated experimentally, although its mode of action is still unclear. It has been suggested that the bone mobilisation caused by metabolic acidosis would increase urinary $\mathrm{Ca}$, causing increased intestinal absorption due to increased calcitriol levels ${ }^{(11)}$. However, high calcitriol levels would not correspond with high urinary Ca because this should correspond with a depressed PTH signal. It has been proposed that lowering systemic $\mathrm{pH}$ would increase the functionality of calcitriol receptors that would have otherwise lost receptivity during metabolic alkalosis $^{(51)}$; however, PTH responsiveness is adequate under physiological conditions with a high systemic $\mathrm{pH}$, as in early lactation. TRPV5 inactivity under acidic conditions combined with the counter-reaction of intestinal TRPV6 represents a plausible mode of action for the prevention of milk fever by lowering the DCAD.

A major difference between renal and intestinal epithelial tissues is the lifespan of the epithelial cells. The intestine is characterised by a cell differentiation process of enterocyte maturation through migration from the crypts to the villi tips (Fig. 1). Intestinal epithelium cells have a short lifespan of approximately $4 \mathrm{~d}$ in poultry ${ }^{(52)}$ and between 1 and $3 \mathrm{~d}$ in mice ${ }^{(53)}$; however, the lifespan of renal cells is approximately $160 \mathrm{~d}$ in poultry ${ }^{(52)}$ and many weeks in rats ${ }^{(54)}$. This constant enterocyte turnover makes it biologically less essential for intestinal cells to have reversible regulatory mechanisms because they will soon be replaced by other enterocytes. Conversely, the lifespan of renal cells is too long to maintain a fixed 


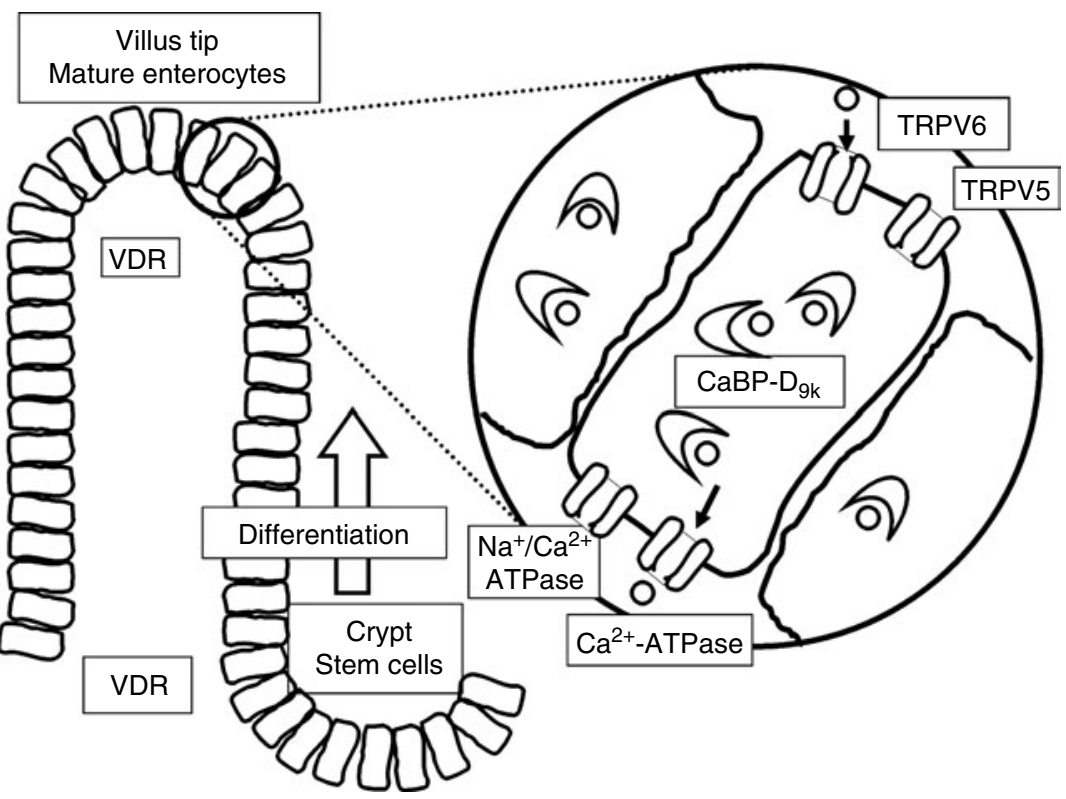

Fig. 1. Regulation of gastrointestinal calcium absorption. Schematic representation of the gastrointestinal transepithelial transport mechanism and its regulation by calcitriol as affected by enterocyte differentiation (based on rat studies). VDR, vitamin D receptor; TRPV5/6, calcium entry channels; CaBP-D ${ }_{9 k}$, intestinal calbindin; $\mathrm{Ca}^{2+}$-ATPase, $\mathrm{Na}^{+} / \mathrm{Ca}^{2+}$, calcium transporters.

regulatory configuration. It has been suggested that enterocytes of rodents acquire Ca transport competence in the early stages of differentiation and express that ability when they mature and reach the villi tips ${ }^{(55)}$. This suggestion is supported by the fact that maximum Ca transport in rats is reached $24-48 \mathrm{~h}$ after the first calcitriol signal ${ }^{(56)}$. This lag time coincides with the time required for the migration of crypt cells to the villi tips ${ }^{(57)}$. The tips of the villi respond to calcitriol by increasing Ca uptake, whereas villus base cells do not respond in this way. The calbindin response is more evident in the base cells than in the cells of the villi tips ${ }^{(58)}$. Additionally, vitamin $\mathrm{D}$ receptor presence in chickens is greater in crypt cells than in tip cells, which suggests that calcitriol induces the production of cells that are more capable of expressing calcitrioldependent genes for active $\mathrm{Ca}$ absorption at the mature stage $^{(59)}$. The main consequence of the different adaptation to the calcitriol signal between the renal and intestinal tissues is the time delay before acquiring Ca transport competence. This delay also exists when the competence is resumed after the calcitriol signal ceases.

Avian intestinal calbindin synthesis peaks $10 \mathrm{~h}$ after calcitriol induction, and its presence in intestinal tissue reaches its maximum at $20 \mathrm{~h}$. This level is maintained up to $48 \mathrm{~h}$ after induction ${ }^{(52)}$. A similar pattern of the calbindin response to calcitriol in chickens has been explained by changes in the calbindin synthesis control mechanisms during enterocyte differentiation because calbindin mRNA is expressed maximally in the basal villus enterocytes ${ }^{(60)}$. In contrast, rat studies show that TRPV6 is only expressed in villi tips ${ }^{(27)}$, which further supports the hypothesis that the delay in positive or negative adaptation is a result of enterocyte differentiation (Fig. 1).
The rapid adaptation of renal reabsorption and delayed adaptation of intestinal absorption can explain the increases in urinary $\mathrm{Ca}$ excretion observed by our group in cows for $2 \mathrm{~d}$ after the withdrawal of a restriction in dietary $\mathrm{Ca}$ availability ${ }^{(29,32)}$. Urinary excretion of $\mathrm{Ca}$ is an effective means to correct positive fluctuations in blood $\mathrm{Ca}^{(1)}$. We observed that when the dietary $\mathrm{Ca}$ restriction was withdrawn, the negative signal for $\mathrm{Ca}$ regulation disappeared, but gastrointestinal absorption remained up-regulated for about $2 \mathrm{~d}$. This surplus of $\mathrm{Ca}$ is corrected by the down-regulation of renal reabsorption, and this down-regulation ceases when intestinal absorption is inactivated again after a $2 \mathrm{~d}$ delay.

Tissue remodelling. Bone remodelling is a very important adaptive mechanism of $\mathrm{Ca}$ homeostatic control. Osseous tissue requires $\mathrm{Ca}$ to maintain its structural function; therefore, this requirement is a factor of blood $\mathrm{Ca}$ clearance. Ramberg et $a l .{ }^{(1)}$ described the role of bone as a controlled, disturbing and controlling signal within the $\mathrm{Ca}$ control system. Bone $\mathrm{Ca}$ represents a quantitatively large source that sustains blood Ca levels in periods of $\mathrm{Ca}$ deficit during early lactation. Nevertheless, this $\mathrm{Ca}$ is not readily available to be brought into the bloodstream. Only a small fraction (less than $10 \mathrm{~g}$ ) is in solution in bone fluids; the remainder is a part of the bone structure ${ }^{(34)}$ and requires bone catabolism to be released. Bone remodelling is a continuous homeorhetic process that results from the anabolic actions of osteoblasts and the catabolic actions of osteoclasts. The prevalence of the activity of either of these cell types results in a net bone calcification or resorption. The control of bone tissue anabolism and catabolism presents great complexity because it involves direct hormonal regulation of the activity of these cells, 
and the differentiation and maturation of these two cell lineages from stem cells is also regulated ${ }^{(61)}$.

Bone remodelling is controlled by local and systemic regulation $^{(62)}$, and it is through systemic hormonal control that it interacts with $\mathrm{Ca}$ homeostasis. The most important hormone affecting bone remodelling is PTH, but its action is tightly coordinated with calcitriol ${ }^{(63)}$. PTH induces bone mobilisation when its signal is maintained over time. However, pulsatory administration of PTH has anabolic effects on bone ${ }^{(64)}$. Calcitriol will cause opposite effects on bone Ca depending on its time of exposure. In contrast to PTH, calcitriol is catabolic in acute applications but suppresses resorption during continuous administration ${ }^{(35)}$; thus, it can be a direct or indirect stimulator of bone formation.

The actions of these hormones on bone metabolism can only be understood as positive and negative signals. The PTH initiates bone resorption to compensate for decreases in blood $\mathrm{Ca}$, but at the same time, it induces the synthesis of calcitriol, which, in turn, activates intestinal Ca absorption. If blood $\mathrm{Ca}$ is normalised by intestinal input, PTH ceases and consequently induces renal excretion of the surplus. In a situation of sufficient dietary $\mathrm{Ca}$, the half-life of PTH is approximately $4 \mathrm{~min}^{(65)}$, compared with a halflife of several hours for calcitriol. This difference would create a pulsatory PTH release and a continuous action of calcitriol to induce bone formation. If intestinal absorption does not suffice, the PTH signal is sustained and bone resorption continues. Through this coupling, bone resorption only occurs when intestinal absorption is insufficient for maintaining Ca homeostasis.

The transient regulatory effects of PTH and calcitriol are explained by their effects on the activity of bone remodelling cells and by the recruitment of these cells by the differentiation process. Osteoclasts are inhibited through the direct hormonal action of calcitonin ${ }^{(66)}$, but their activation is mediated indirectly through osteoblasts ${ }^{(67)}$. Osteoblasts have specific receptors for both PTH and calcitriol, and they act on the pre-osteoclasts by inducing a transformation into active osteoclasts. The activation of existing osteoclasts occurs within $6 \mathrm{~h}$, but an increase in osteoclasts may take $2 \mathrm{~d}$. In the case of sufficient $\mathrm{Ca}$, this process is reversed by a decrease in osteoclasts by day 7 , although bone mobilisation is sustained by a lack of sufficient dietary $\mathrm{Ca}^{(35)}$.

The nature of the regulation of bone remodelling has several practical implications for the transition cow. First, adaptations do not occur fast enough after a sudden change in blood Ca clearance. As with intestinal adaptation, the involvement of a cell differentiation process delays any adaptation for approximately $2 \mathrm{~d}$. Pregnant cows required $48 \mathrm{~h}$ of $\mathrm{PTH}$ stimulation to effectively mobilise bone ${ }^{(68)}$. This lag time coincides with the time around calving when the cow suffers from hypocalcaemia. A second implication is that bone remodelling occurs only if the adaptation of intestinal absorption is not enough to compensate for $\mathrm{Ca}$ clearance. These implications were clearly illustrated in an experiment where cows that had been fed a low-Ca diet for weeks were administered an EDTA infusion. The bone resorption marker hydroxyproline remained low during dietary restriction and peaked $2 \mathrm{~d}$ after the EDTA infusion ${ }^{(34)}$. Finally, the pharmacological induction of adaptation by injections of vitamin D metabolites can yield effects that are the opposite of those intended. If bone adaptation is reversed 1 week after the application of sufficient dietary $\mathrm{Ca}$, the calving challenge may occur when bone resorption is inhibited. This observation provides an explanation for some of the problems that were observed with the use of vitamin $\mathrm{D}$ to prevent milk fever ${ }^{(69,70)}$. With the use of vitamin $\mathrm{D}$, the timing of the application was critical to prevent the disease.

Conclusion on adaptive mechanisms. Intestinal absorption and bone resorption present a delay of approximately 1 or $2 \mathrm{~d}$ when adapting to an increased Ca clearance from the blood. This time-frame coincides with the period around calving when cows suffer from hypocalcaemia. Renal adaptation is much faster, but reabsorption of $\mathrm{Ca}$ in the kidney is quantitatively too small to enable the cow to cope with the challenge of homeostasis around calving.

Induction of $\mathrm{Ca}$ homeostasis adaptations before calving should trigger gastrointestinal absorption, which is the first limiting mechanism in the reactions against hypocalcaemia. If the challenge is beyond the capacity of intestinal $\mathrm{Ca}$ absorption, bone remodelling will contribute to compensate for the Ca clearance from the blood.

\section{Dietary-induced modulation of calcium metabolism}

For many decades, dairy nutritionists have searched for a dietary strategy to prevent milk fever. The preference for dietary prevention is related to the ease of application. Moreover, nutrient imbalances tend to be understood as nutritional problems, although, as already discussed, milk fever should be considered to be a failure of physiological adaptation rather than a case of inadequate nutrient supply. In the middle of the last century, dietary strategies, such as vitamin D supplementation and changes in dietary $\mathrm{Ca}: \mathrm{P}$ ratios, were proposed for the prevention of milk fever ${ }^{(71)}$. There is also a long history of studying low-Ca diets and the reduction of the DCAD to prevent milk fever. Presently, hypocalcaemia is managed in practice by integrated approaches that act on all known nutritional risk factors. Dietary preventive strategies and nutritional risk factors have been properly reviewed elsewhere ${ }^{(11,72)}$; therefore, only the effect of nutritional strategies as inducers of the adaptation of $\mathrm{Ca}$ metabolism will be discussed here.

\section{Non-nutritional supply of vitamin D metabolites}

Vitamin D, its hydroxylated forms (hydroxylation in position 1 or 25), and calcitriol in oral or injected applications 
have been extensively tested for milk fever prevention in the past several decades ${ }^{(73-76)}$ as well as more recently ${ }^{(33)}$. These experiences have been reviewed elsewhere ${ }^{(77)}$. As expected, these acute applications induce hypercalcaemia by acting on gastrointestinal transport but not by activating bone resorption ${ }^{(75)}$. These treatments reflect the abovedescribed actions of calcitriol on the gastrointestinal tract, where serum $\mathrm{Ca}$ is increased but reaches a maximum only after $24 \mathrm{~h}^{(76)}$. The protection that these applications may provide appears to be highly dependent on the timing of the application in relation to calving ${ }^{(73)}$. These products received a large amount of attention in the past few decades. Although some injected applications remain in use, nutritional applications are difficult because the effective doses are too close to the toxic doses ${ }^{(69)}$ and exceed some legal restrictions of vitamin D feeding (for example, that of the European Union). Furthermore, if the effectiveness is dependent on the timing of the application before calving, the implementation of these strategies is difficult in practice, as the exact calving date cannot be predicted days in advance.

Acute administration of vitamin $\mathrm{D}$ metabolites has been proven to modify $\mathrm{Ca}$ metabolism. The effects observed can be generally recognised as being analogous to the natural action of calcitriol. Nevertheless, it is our understanding that these applications do not constitute a feasible nutritional strategy to anticipate the adaptation of $\mathrm{Ca}$ metabolism to the upcoming lactation state. If the artificially induced up-regulation of $\mathrm{Ca}$ absorption coincides with the increased Ca clearance associated with calving, hypocalcaemia may be prevented. Nevertheless, if this artificial calcitriol signal is introduced too early and creates a hypercalcaemic state, the homeostatic system will be down-regulated to counteract the artificial calcitriol signal. PTH depression associated with the acute applications of vitamin $\mathrm{D}$ has been shown to induce hypercalciuria $^{(78)}$, as well as induce bone anabolism when combined with the sustained calcitriol signal, and ultimately cause soft tissue calcification ${ }^{(69)}$. In our opinion, this would be an undesirable configuration of the homeostatic system of $\mathrm{Ca}$ during calving.

\section{Low-calcium diets}

Once milk fever was understood as a failure of $\mathrm{Ca}$ homeostasis, low-Ca diets were proposed to challenge Ca homeostasis and anticipate the necessary adaptation to calving. This strategy was proven effective in numerous studies $^{(79-84)}$. The efficacy of this strategy has been suggested to be close to $100 \%$ when daily $\mathrm{Ca}$ intake is kept below $20 \mathrm{~g} / \mathrm{d}^{(72)}$. Creating an extreme dietary Ca shortage represents a preventive strategy that induces the adaptation of $\mathrm{Ca}$ metabolism. At the same time, dietary $\mathrm{Ca}$ within the common range is one of the multiple dietary factors that define milk fever risk. The effect of dietary $\mathrm{Ca}$ on the incidence of milk fever has been characterised as quadratic in two meta-analyses ${ }^{(85,86)}$. These models identify a lower risk at low and high Ca intakes within the normal range.

Dietary $\mathrm{Ca}$ affects the incidence of milk fever by quadratic means with a maximum incidence at $11.6 \mathrm{~g}$ dietary $\mathrm{Ca}$ per $\mathrm{kg}$ DM intake $(\mathrm{DMI})^{(85)}$ or $13.5 \mathrm{~g}$ dietary $\mathrm{Ca}$ per $\mathrm{kg}$ $\mathrm{DM}^{(86)}$. Apparently, a low level of dietary $\mathrm{Ca}$ initiates active $\mathrm{Ca}$ absorption before calving, thus preventing milk fever ${ }^{(82-84)}$. However, a high level of $\mathrm{Ca}$ intake around and after parturition allows for high passive $\mathrm{Ca}$ absorption, and this may compensate for the drain of $\mathrm{Ca}$ into the milk around calving.

Exploration of low-Ca diets has increased our understanding of the aetiology of the disorder, but reproducing the high preventive effectiveness of synthetic low-Ca diets described in the literature remains a challenge in practice. Reducing the $\mathrm{Ca}$ content of the diet is used as a risk factor to manage milk fever in a multifactorial approach. Nevertheless, formulating a dry cow ration below $1.5 \mathrm{~g}$ dietary Ca per $\mathrm{kg}$ DM is difficult to achieve with the main nutritional targets of these rations. Green forages exceed that $\mathrm{Ca}$ level by several-fold, leaving cereal straws as the only suitable source of effective fibre. These practical difficulties have restricted the implementation of low-Ca diets as a specific strategy for milk fever prevention.

\section{Reduction of the dietary cation-anion difference}

In commercial nutritional practice, the most widespread and successful dietary method for the prevention of milk fever has been the modification of the DCAD, which induces a moderate state of metabolic acidosis. The prophylactic value of acidifying blood and urine through the dietary modulation of the DCAD has been extensively documented $^{(49,87-90)}$. The dietary cation-anion balance is calculated as the sum of the cation equivalents of $\mathrm{Na}$ and $\mathrm{K}$ content in the diet minus the anion equivalents of $\mathrm{Cl}$ and $S^{(90)}$ and is expressed in meq/kg DM in feed. The reduction of the DCAD is achieved in practice with the use of mineral salts containing $\mathrm{S}$ or $\mathrm{Cl}$ without $\mathrm{Na}$ or $\mathrm{K}$, the so-called anionic salts.

Supplying anionic salts is a preventive dietary intervention, and the DCAD is also a dietary risk factor. The effect of the DCAD level on milk fever incidence has been modelled by linear regressions ${ }^{(86,91)}$. These models describe a curvilinear relationship between the DCAD and milk fever risk when the non-linear transformations of milk fever incidence data are considered. Increasingly, negative DCAD values approach minimal milk fever incidences asymptotically for a fixed set of other dietary factors ${ }^{(11)}$. The urinary $\mathrm{pH}$ and urinary $\mathrm{Ca}$ respond to the DCAD in a similar fashion to the reduction of milk fever with a decreasing DCAD. Urinary $\mathrm{pH}^{(49,86,91)}$ and urinary Ca excretion ${ }^{(49)}$ respond to DCAD with greater slopes as DCAD becomes negative. 
The mode of action of the preventive effect of a low DCAD is still under discussion. A high DCAD has been explained as a negative factor for $\mathrm{Ca}$ metabolism ${ }^{(89,92,93)}$ rather than a negative DCAD as a positive factor against milk fever. It has been proposed that metabolic alkalosis reduces renal responsiveness to $\mathrm{PTH}^{(51)}$ and that this may be reversed by metabolic acidification. Furthermore, improved responsiveness to calcitriol at a lower DCAD has been suggested $^{(92)}$. However, a positive DCAD is not unique to the periparturient period. In fact, a positive DCAD is common in lactation diets, and its increase is advised for highly fermentable diets ${ }^{(94)}$. Under these conditions, Ca homeostasis is adequately maintained during lactation.

Alternatively, the preventive effect of a low dietary DCAD can be explained as an inducer of the adaptation of $\mathrm{Ca}$ metabolism in the prevention of milk fever. When the DCAD is low enough, it can increase apparent $\mathrm{Ca}$ absorption in cows ${ }^{(48)}$ as a response to the effect of the DCAD on urinary $\mathrm{Ca}$ excretion. Urinary $\mathrm{Ca}$ clearance from the blood must therefore be compensated at the first instance it occurs by increased intestinal absorption. This is because the reduction of endogenous intestinal $\mathrm{Ca}$ secretion is not among the control mechanisms of $\mathrm{Ca}$ homeostasis $^{(1)}$. As discussed in the Transepithelial transport processes section, the molecular mechanisms of hypercalciuria that is induced by anionic salts are now better understood from mouse studies as a result of a $\mathrm{pH}$-related failure of renal TRPV5. It is plausible to suggest that lowering the DCAD prevents milk fever in a similar way to lowering dietary $\mathrm{Ca}$. Both create a Ca deficit before calving and induce the adaptation of Ca metabolism by activating gastrointestinal absorption. If this is insufficient to compensate for urinary Ca losses, bone Ca resorption will also be activated.

\section{Dietary inclusion of calcium antagonists}

In the last decade, the principle of low $\mathrm{Ca}$ to prevent milk fever has been reinvented with dietary interventions to reduce $\mathrm{Ca}$ availability without modifying $\mathrm{Ca}$ intake. Zeolite clays have consistently shown a reduced milk fever incidence ${ }^{(95-102)}$. This effectiveness is similar to that of the synthetic low-Ca diets. The mode of action of zeolites is still up for discussion. The initial hypothesis was that intestinal binding of $\mathrm{Ca}$ would challenge $\mathrm{Ca}$ absorption; however, it has been recently proposed that the induction of hypophosphataemia by the product may play an active role in milk fever prevention ${ }^{(103)}$.

Zeolites have demonstrated great potential for the dietary prophylaxis of milk fever. However, a major drawback of this application is a depression of DMI. Initial data do not report the large effects on DMI that were later observed $^{(101,102)}$. Those initial studies indicate that leftover feed was minimal ${ }^{(95,103)}$. This may suggest restricted feeding that would not allow for observing differences in the voluntary feed intake. However, the effect on
DMI depends on the product dose, and a dose with a compromise between effectiveness and DMI depression was determined to be $23 \mathrm{~g} / \mathrm{kg}$ DM in another study ${ }^{(102)}$.

A different approach for reducing $\mathrm{Ca}$ in the diet was proposed by Wilson ${ }^{(104,105)}$. In his case, unsaturated fat was used to decrease $\mathrm{Ca}$ absorption and induce the adaptation of $\mathrm{Ca}$ homeostasis before parturition with apparent success. Dietary fat has been considered an antagonist of $\mathrm{Ca}^{(106)}$, but the magnitude of this effect is questionable in ruminants because the Ca complexation with the fat in the rumen can dissociate in the duodenum ${ }^{(107)}$ An additional drawback to this approach is that feeding fat before calving also has a negative effect on DMI ${ }^{(108)}$.

It would be desirable to lower the dietary availability of Ca without inducing DMI depression. Among the natural components known to reduce Ca availability, phytic acid is abundantly available in rice bran; therefore, this feed may be a potential alternative. This feed has no known negative effects on DMI and has an adequate feed value for ruminants. Phytic acid from rice bran has been used to reduce dietary $\mathrm{Ca}$ availability to prevent renal calculi in humans ${ }^{(109,110)}$. Among common cereal brans, rice bran contains the highest phytic acid levels and presents the greatest in vitro binding potential $(20 \mathrm{~g} \mathrm{Ca} / \mathrm{kg} \text { bran })^{(111)}$.

It should be noted that phytic acid is rumen degradable ${ }^{(112)}$; therefore, dietary inclusion of rice bran would not represent a viable alternative to zeolites. Ruminal degradation of phytic acid has been studied extensively in recent decades to determine the need for supplemental $\mathrm{P}$ in ruminants and minimise its environmental impact. The results of these studies demonstrated that ruminal degradation of phytic acid is associated with the degradation of protein and that feed treatments used to promote a higher rumen protein escape fraction also result in lowered digestibility values for $\mathrm{P}^{(113-115)}$. Phytic acid in rice bran can be protected from ruminal degradations by different treatments ${ }^{(29,116)}$.

Rumen-protected rice bran can induce the adaptation of Ca metabolism in cows ${ }^{(29)}$. This effect is caused by very low Ca content and the action of lowering the dietary availability of $\mathrm{Ca}^{(32)}$. The prophylactic value of this feed against milk fever is currently under evaluation by our group, and the preliminary results indicate that rumen-protected rice bran can improve calcaemia recovery after calving ${ }^{(117)}$.

\section{Mechanistic analysis of the adaptation of calcium homeostasis at calving}

In the dry period, dairy cows do not produce milk and thus have a low metabolic expenditure of Ca compared with the gastrointestinally (GI) available Ca. Active absorption becomes dormant, and passive paracellular absorption from the gut is sufficient to cover basal Ca requirements. Any surplus is excreted into the urine.

Adaptation can be stimulated either by increasing $\mathrm{Ca}$ clearance from the blood or by reducing intestinally available 
Fig. 2. Diagram of the digestive and physiological fate of calcium in pre-calving dairy cows. GI, gastrointestinally.

Ca. Either of these two actions can cause passive Ca absorption to be insufficient to compensate for metabolic needs, which would trigger the adaptation of $\mathrm{Ca}$ homeostasis. In the Dietary-induced modulation of calcium metabolism section, we have discussed several dietary strategies to modulate $\mathrm{Ca}$ metabolism. Nevertheless, to understand the effectiveness of these strategies for the prevention of milk fever, it is important to quantify the effects of these dietary strategies on Ca clearance and GI available Ca. A schematic of the factors affecting these effects is described in Fig. 2.

\section{Estimation of blood calcium clearance}

The factors defining blood $\mathrm{Ca}$ clearance are as follows: endogenous faecal output, urinary excretion, net bone deposition, fetal requirements and lactation requirements.

The endogenous faecal losses are the sum of the $\mathrm{Ca}$ excreted into the gastrointestinal tract in the saliva, bile, gastric juices, pancreatic juices and other intestinal secretions. Endogenous faecal losses are a function of body weight and feed intake ${ }^{(118)}$ and represent most of the maintenance requirements of $\mathrm{Ca}$. Endogenous faecal clearance is largely independent of $\mathrm{Ca}$ intake ${ }^{(118,119)}$.
In the analysis presented here, it will be assumed that these levels are $6 \mathrm{~g} / \mathrm{d}$ in multiparous dry cows and $5.5 \mathrm{~g} /$ $\mathrm{d}$ in dry heifers based on values from the literature ${ }^{(120-123)}$, which are displayed in Table 1.

Urinary excretion is a small fraction of the maintenance Ca requirements. As already described, urinary Ca can be increased or minimised during the time lag for intestinal and bone adaptation, but reabsorption is as high as $99 \%{ }^{(1)}$. Therefore, urinary losses are as low as $0.4 \mathrm{~g} / \mathrm{d}^{(48)}$ and $0.8 \mathrm{~g} / \mathrm{d}^{(87)}$. An exception to this rule is when dietaryinduced metabolic acidosis causes hypercalciuria. The urinary $\mathrm{Ca}$ excretion increases in a curvilinear fashion as the systemic $\mathrm{pH}$ decreases and can be as high as $6^{(48)}$, $5 \cdot 3^{(87)}$ or $7 \cdot 9 \mathrm{~g} / \mathrm{d}^{(124)}$.

The relationship between the DCAD and urinary $\mathrm{Ca}$ has been described by Roche et al. ${ }^{(49)}$. To translate urinary $\mathrm{Ca}$ excretion values expressed as a fraction of creatinine excretion into daily $\mathrm{Ca}$ excretion, it is necessary to assume a constant daily creatinine excretion for the dry cow. In this model, daily creatinine excretion is considered to be $17.5 \mathrm{~g} / \mathrm{d}$ based on estimates from literature references $^{(125,126)}$. In this mechanistic analysis, urinary $\mathrm{Ca}$ excretion is estimated as a function of the DCAD with an adapted version of the equation from Roche et $a l^{(49)}$.

Table 1. Endogenous faecal calcium in cattle measured by the isotope dilution technique (Mean values and standard deviations)

\begin{tabular}{|c|c|c|c|c|c|}
\hline \multirow[b]{2}{*}{ Bovine animal type } & \multicolumn{2}{|c|}{$\begin{array}{c}\text { Body } \\
\text { weight }(\mathrm{kg})\end{array}$} & \multicolumn{2}{|c|}{$\begin{array}{l}\text { Endogenous } \\
\text { faecal } \mathrm{Ca}(\mathrm{g} / \mathrm{d})\end{array}$} & \multirow[b]{2}{*}{ Reference } \\
\hline & Mean & SD & Mean & $\mathrm{SD}$ & \\
\hline Lactating Jersey/Guernsey cows & 327 & 37 & $6 \cdot 8$ & $1 \cdot 2$ & $\begin{array}{l}\text { Comar et al. }(1953)^{(121)} \\
\text { Visek et al. }(1953)^{(122)}\end{array}$ \\
\hline Lactating heifers & 368 & 44 & 5.5 & $2 \cdot 1$ & \\
\hline Steers & 340 & 74 & $4 \cdot 6$ & 0.7 & \\
\hline $\begin{array}{l}\text { Mature steers } \\
\text { Young steers }\end{array}$ & $\begin{array}{l}485 \\
181\end{array}$ & $\begin{array}{l}87 \\
39\end{array}$ & $\begin{array}{l}7 \cdot 6 \\
2 \cdot 8\end{array}$ & $\begin{array}{l}1 \cdot 7 \\
0.5\end{array}$ & Hansard et al. $(1957)^{(120)}$ \\
\hline Non-lactating dairy cows & 678 & - & $5 \cdot 6$ & $1 \cdot 1$ & Martz et al. (1999) $)^{(123)}$ \\
\hline
\end{tabular}


This adaptation assumes that the non-reported units for the $\mathrm{Ca}$ :creatinine ratio were $\mathrm{mg} / 100 \mathrm{ml}$ per $\mathrm{mmol} / \mathrm{l}$ and the above-mentioned daily creatinine excretion (Table 2). This equation predicts an excretion of approximately $0.5 \mathrm{~g} \mathrm{Ca} / \mathrm{d}$ for a high DCAD and approximately $7 \mathrm{~g} / \mathrm{d}$ for a low DCAD. The adapted equation was validated by ten dietary treatments that were described in four studies from the literature. Observed and predicted daily urinary Ca excretions produced an $R^{2}$ of 0.76 (Table 2).

During the Ca deficit, the homeostatic system can reduce the urinary excretion to urinary Ca losses that are as low as $0.1 \mathrm{mmol} \mathrm{Ca}$ per $\mathrm{g}$ creatinine ${ }^{(29)}$ (approximately $0.07 \mathrm{~g} / \mathrm{d}$ ). The aim of this simulation is to predict whether a $\mathrm{Ca}$ imbalance can induce this and other adaptive reactions. Therefore, this situation is not included in the model.

The net bone deposition of Ca depends on the longterm Ca balance of the cow. At the end of the dry period, multiparous cows should have replenished the bone reserves that were mobilised during early lactation. However, when feeding Ca levels are as low as $5.2 \mathrm{~g} / \mathrm{kg}$ $\mathrm{DM}$ in the lactation diet, a positive Ca balance is regained within the first half of the lactation period ${ }^{(127)}$, which allows enough time to replenish the $\mathrm{Ca}$ reserves before the dry period. Heifers instead are still growing, and their increase in body mass is a relevant factor for $\mathrm{Ca}$ clearance from the blood. The US National Research Council proposes a factorial approach to derive net $\mathrm{Ca}$ requirements, in which growth needs are a function of daily weight gain, body weight and mature weight gain $^{(128)}$. According to the National Research Council, a heifer weighing $700 \mathrm{~kg}$, aiming for a mature weight of $750 \mathrm{~kg}$ and growing at $800 \mathrm{~g} / \mathrm{d}$, would have a net $\mathrm{Ca}$ requirement for growth of $8 \mathrm{~g} / \mathrm{d}$.

The intrinsic cause of milk fever is the discontinuity of the $\mathrm{Ca}$ yields to the calf between fetal and lactation requirements. The factorial model of the National Research Council $^{(128)}$ estimates fetal Ca requirements in the last days of pregnancy to be approximately $7 \mathrm{~g} / \mathrm{d}$. This contrasts with the Ca content of the first colostrums that represents approximately $23 \mathrm{~g}$ in the dairy cow $^{(129)}$.

\section{Gastrointestinally available pool}

The GI available pool of $\mathrm{Ca}$ is the amount of $\mathrm{Ca}$ present in the lumen of the complete gastrointestinal tract that can potentially be absorbed. Ca absorption is a regulated process that differentiates between availability and absorption. Although Ca availability influences absorption by allowing passive inflow, $\mathrm{Ca}$ absorption only reflects the dietary $\mathrm{Ca}$ availability under conditions of $\mathrm{Ca}$ shortage. The endogenous $\mathrm{Ca}$ secretions and the fraction of dietary $\mathrm{Ca}$ that becomes available during the digestion process constitute the GI available pool. In this pool, we exclude the fraction that may become unavailable during digestion (for example, via precipitation with other dietary components).

Dietary $\mathrm{Ca}$ intake is defined by the total feed intake and the $\mathrm{Ca}$ content of the feeds, plus any supplemental Ca. Voluntary feed intake is a very important factor that affects the $\mathrm{Ca}$ intake of the transition cow because it is greatly affected by the diet characteristics, the health status of the animal and calving. Ca content in feeds is highly variable in feed value tables ${ }^{(128)}$. Ca content can range from 12 to $15 \mathrm{~g} / \mathrm{kg} \mathrm{DM}$ in legume forages, grasses are in the range of 4 to $8 \mathrm{~g} / \mathrm{kg} \mathrm{DM}$, and maize silages and cereal straws are mostly within 2 to $4 \mathrm{~g} / \mathrm{kg}$ DM. Among the concentrates, most grains are poor sources of $\mathrm{Ca}$ (mostly under $1 \mathrm{~g} / \mathrm{kg} \mathrm{DM}$ ), and the protein concentrates contain $\mathrm{Ca}$ in a range of 3 to $6 \mathrm{~g} / \mathrm{kg}$ DM. Depending on the ration formulation, the final $\mathrm{Ca}$ content is variable, but there is a clear association between the effective fibre and $\mathrm{Ca}$ content.

A negative correlation exists between the dietary $\mathrm{Ca}$ content and $\mathrm{Ca}$ availability. The model presented by the US National Research Council in $2001^{(128)}$ assigns an availability coefficient of 0.6 for $\mathrm{Ca}$ in concentrates and maize silages (low $\mathrm{Ca}$ content) and 0.3 for $\mathrm{Ca}$ in other forages (high Ca content). This negative correlation greatly reduces the variability of the available $\mathrm{Ca}$ in the rations. In the present model, the availability of $\mathrm{Ca}$ in the rations is assumed to be inversely proportional to their total $\mathrm{Ca}$ content. Rations below $2 \mathrm{~g} \mathrm{Ca} / \mathrm{kg} \mathrm{DM}$ are calculated with

Table 2. Urinary calcium excretion in cattle as affected by the dietary cation-anion difference (DCAD)

\begin{tabular}{|c|c|c|c|}
\hline Reference & $\begin{array}{c}\text { DCAD } \\
\text { (meq/kg DM) }\end{array}$ & $\begin{array}{l}\text { Urinary } \\
\mathrm{Ca}(\mathrm{g} / \mathrm{d})\end{array}$ & $\begin{array}{l}\text { Urinary Ca }(\mathrm{g} / \mathrm{d}) \\
\text { model prediction* }\end{array}$ \\
\hline \multirow[t]{2}{*}{ Schonewille et al. (1994) } & -170 & $6 \cdot 1$ & $7 \cdot 61$ \\
\hline & 276 & 0.4 & 0.91 \\
\hline \multirow[t]{4}{*}{ Vagnoni \& Oetzel $(1998)^{(124)}$} & -63 & $6 \cdot 87$ & $5 \cdot 44$ \\
\hline & -40 & $7 \cdot 87$ & 5.02 \\
\hline & -51 & $6 \cdot 70$ & $5 \cdot 22$ \\
\hline & 203 & 0.92 & 1.59 \\
\hline \multirow[t]{2}{*}{ Schonewille et al. (1999) } & -230 & $11.44 \dagger$ & $8 \cdot 98$ \\
\hline & 332 & $1.06 \dagger$ & 0.51 \\
\hline \multirow[t]{2}{*}{ Roche et al. (2007) $)^{(87)}$} & -200 & $5 \cdot 3$ & $8 \cdot 28$ \\
\hline & 180 & 0.8 & $1 \cdot 83$ \\
\hline
\end{tabular}

* Prediction of daily urinary Ca excretion from the DCAD (meq/kg DM) using the equation from Roche et al. (2003) (49) $^{(0)}$ adjusted in units and assuming a daily creatinine excretion of $17.5 \mathrm{~g}$. Urinary $\mathrm{Ca}(\mathrm{g} / \mathrm{d})=1.5470(0.001$ $\left.(0.1 \mathrm{DCAD})^{2}-0.1075(0.1 \mathrm{DCAD})+4.794\right)$. Linear fit between the literature observations and the predicted values: $R^{2} 0.76$.

†Calculated from the creatinine ratio, assuming a daily creatinine excretion of $17.5 \mathrm{~g}$. 
Table 3. Estimated daily blood calcium clearance and the available gastrointestinal calcium pool in different pre-calving scenarios in multiparous dairy cows fed two levels of calcium, heifers, multiparous cows fed a low-dietary cation-anion difference (DCAD) diet and multiparous cows fed a calcium antagonist

\begin{tabular}{|c|c|c|c|c|c|c|}
\hline & Mid-low Ca & Mid-high Ca & Heifer & Low-Ca diet & Low-DCAD diet & Ca binder \\
\hline Endogenous faecal excretion (g) & $6 \cdot 0$ & $6 \cdot 0$ & 5.5 & $6 \cdot 0$ & $6 \cdot 0$ & $6 \cdot 0$ \\
\hline Urinary excretion (g) & 0.7 & 0.7 & 0.7 & 0.7 & $7 \cdot 2$ & 0.7 \\
\hline Bone deposition $(\mathrm{g})$ & - & - & $8 \cdot 0$ & - & - & - \\
\hline Fetal needs $(\mathrm{g})$ & $7 \cdot 0$ & $7 \cdot 0$ & $7 \cdot 0$ & $7 \cdot 0$ & $7 \cdot 0$ & $7 \cdot 0$ \\
\hline Total BCC (g) & 13.7 & $13 \cdot 7$ & $21 \cdot 2$ & $13 \cdot 7$ & $20 \cdot 2$ & 13.7 \\
\hline DM intake $(\mathrm{kg})$ & $14 \cdot 0$ & 14.0 & $12 \cdot 0$ & $14 \cdot 0$ & $13 \cdot 0$ & $14 \cdot 0$ \\
\hline Dietary $\mathrm{Ca}(\mathrm{g} / \mathrm{kg} \mathrm{DM})$ & $2 \cdot 5$ & 5.5 & 4.0 & 1.5 & $4 \cdot 0$ & 4.0 \\
\hline $\mathrm{DCAD}(\mathrm{meq} / \mathrm{kg} \mathrm{DM})$ & 300 & 300 & 300 & 300 & -150 & 300 \\
\hline Ca intake (g) & $35 \cdot 0$ & $77 \cdot 0$ & $48 \cdot 0$ & $21 \cdot 0$ & $52 \cdot 0$ & $56 \cdot 0$ \\
\hline Availability & 0.58 & 0.43 & 0.50 & 0.60 & 0.50 & 0.50 \\
\hline Available $\mathrm{Ca}$ intake $(\mathrm{g})$ & $20 \cdot 1$ & $32 \cdot 7$ & $24 \cdot 0$ & $12 \cdot 6$ & $26 \cdot 0$ & $28 \cdot 0$ \\
\hline Gastrointestinal precipitation (g) & - & - & - & - & - & $15 \cdot 0$ \\
\hline Total GIAP (g) & $26 \cdot 1$ & 38.7 & 29.5 & $18 \cdot 6$ & $32 \cdot 0$ & $19 \cdot 0$ \\
\hline BCC:GIAP ratio & 0.53 & 0.35 & 0.72 & 0.74 & 0.63 & 0.72 \\
\hline
\end{tabular}

BCC, blood Ca clearance; GIAP, gastrointestinally available pool.

an availability coefficient of $0 \cdot 6$, and rations above $8 \mathrm{~g} \mathrm{Ca} /$ $\mathrm{kg}$ DM are calculated with an availability coefficient of $0 \cdot 3$. Rations with a Ca content between 2 and $8 \mathrm{~g} / \mathrm{kg}$ DM are calculated with intermediate values between $0 \cdot 6$ and $0 \cdot 3$, which is determined by a simple linear function of their Ca content (availability $=0.7-0.05 \times \mathrm{Ca}$ ).

Ca availability is not simply an intrinsic property of the feeds. Digestive processes can result in the formation of chemical compounds containing $\mathrm{Ca}$ that are not susceptible to intestinal absorption. Endogenous faecal Ca can also be subject to availability loss. Precipitation with zeolites or phytate would be examples of this fraction, which is subtracted from the GI available pool.

\section{Prediction of metabolic adaptation from the ratio between calcium clearance and gastrointestinally available calcium}

It is not easy to predict the situations in which dietary regulatory adaptation will take effect. Both $\mathrm{Ca}$ clearance and intestinal availability do not present constant rates in time. Therefore, choosing days as a time unit for assessment may be inadequate. The clearance rate of $\mathrm{Ca}$ into colostrum may be greater at a given moment than as a daily average. Additionally, the gastrointestinal availability will depend on the transit speed through the tract and the residence times of chyme in the different compartments $^{(44)}$. Despite this, the degree of $\mathrm{Ca}$ adaptation before calving should be directly related to $\mathrm{Ca}$ clearance before calving and inversely related to GI available Ca. The ratio of these factors represents the fraction of the GI available $\mathrm{Ca}$ that is absorbed to compensate for the $\mathrm{Ca}$ clearance during homeostasis. This ratio should be indicative of the point beyond which passive absorption would not suffice and active absorption would be required for Ca homeostasis (Fig. 2).

The above-described model has been used to evaluate a representative set of dietary and physiological pre-calving scenarios (Table 3). These include the high and low range of dietary $\mathrm{Ca}$ contents in diets fed to multiparous cows and an average heifer diet. Furthermore, the following three milk fever prevention strategies are presented: a Ca diet low enough for milk fever prevention, a low-DCAD diet, and a hypothetical Ca diet in which the available $\mathrm{Ca}$ is reduced by $15 \mathrm{~g}$ using a dietary antagonist. At first glance, this model shows that multiparous cows absorb a relatively small fraction of the GI available Ca throughout a typical range of dietary $\mathrm{Ca}$. Heifers instead absorb a fraction of the available Ca with the estimates for milk fever prevention strategies. This finding explains why heifers are considered to be less susceptible to hypocalcaemia. The ratio between the $\mathrm{Ca}$ clearance and GI available $\mathrm{Ca}$ seems to be indicative of the adaptation of $\mathrm{Ca}$ metabolism before calving. Within the assumptions of the proposed model, it seems that before calving, when nearly $70 \%$ of the intestinally available $\mathrm{Ca}$ is absorbed, the incidence of hypocalcaemia is reduced.

The effect of parity and dietary $\mathrm{Ca}$ on the calculated ratio of Ca clearance:GI available $\mathrm{Ca}$ is further explored in Fig. 3. The model clearly explains the different susceptibilities of heifers and cows to milk fever in terms of the induction

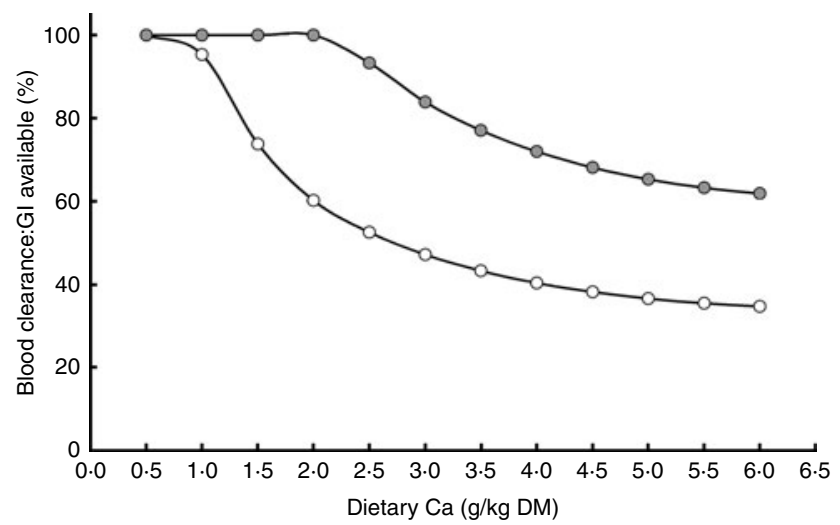

Fig. 3. Predicted effect of dietary calcium ( $g / \mathrm{kg} \mathrm{DM}$ ) on the fraction of gastrointestinally (GI) available calcium required for physiological purposes in heifers (---) and multiparous cows (-O-). 
of metabolic adaptation. It predicts that heifers will always need to absorb more than $60 \%$ of the available intestinal $\mathrm{Ca}$ even at high dietary $\mathrm{Ca}$; however, older cows will absorb a much smaller fraction of the available $\mathrm{Ca}$. It is also remarkable that the curve increases its slope as the dietary level decreases to $1.5 \mathrm{~g} / \mathrm{kg}$ DM (about $20 \mathrm{~g} / \mathrm{d}$ ). This value is the dietary Ca level that is considered to effectively prevent milk fever ${ }^{(72)}$. These estimates explain the absence of changes in Ca homeostasis in heifers observed by our group ${ }^{(130)}$. The Ca regulation of heifers is adapted because their $\mathrm{Ca}$ clearance that is driven by growth is high in relation to their GI available $\mathrm{Ca}$.

The model is also used to study the effect of the DCAD on urinary $\mathrm{Ca}$ excretion and the fraction of $\mathrm{GI}$ available $\mathrm{Ca}$ that is absorbed at different dietary levels (Fig. 4). Reduction of the DCAD increases the fraction absorbed. At the recommended DCAD levels of -200 and $-100 \mathrm{meq} / \mathrm{kg} \mathrm{DM}$, the blood Ca clearance:GI available $\mathrm{Ca}$ ratios are in the range of those calculated for heifers with common dietary Ca levels. This finding supports the milk fever prevention value of this strategy and explains its mode of action through the induction of metabolic adaptation.

The reports on the effect of dietary Ca levels on the DCAD have been controversial. While some authors proposed that increasing dietary Ca may have a preventive value in low-DCAD diets ${ }^{(129)}$, others suggest that the quadratic effect of dietary $\mathrm{Ca}$ on milk fever incidence is independent from the DCAD level ${ }^{(86)}$. The present mechanistic simulation (Fig. 4) predicts the preventive value of lowering $\mathrm{Ca}$, even at a low DCAD. This effect would not be linear but curvilinear, suggesting a smaller stimulation of the adaptation to changes in dietary $\mathrm{Ca}$ in the higher range than in the lower range. This relationship would correspond with the left slope of the quadratic relationship that was empirically determined by Lean et $a{ }^{(86)}$ and earlier by Oetzel ${ }^{(85)}$. The present model is limited to milk fever prevention through metabolic adaptation. Therefore, it is not suitable to describe the

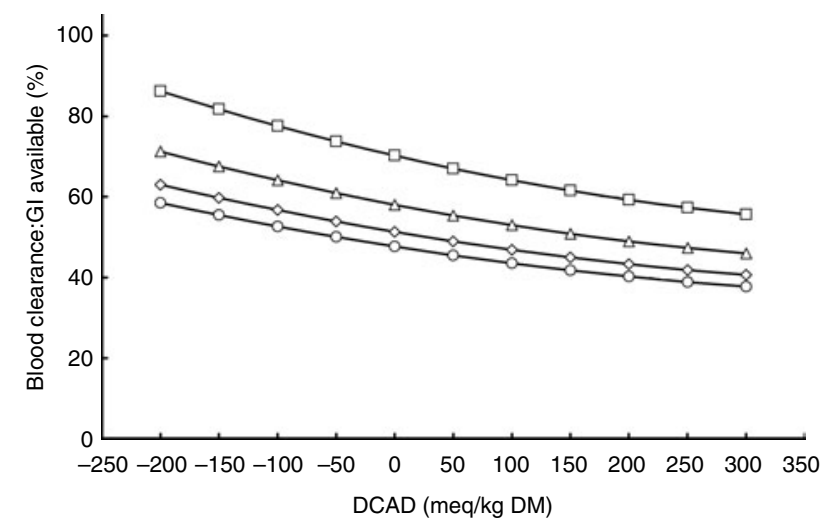

Fig. 4. Predicted effect of the dietary cation-anion difference (DCAD) on the fraction of gastrointestinally (GI) available calcium required for physiological purposes at different levels of dietary calcium: (-O-), $5.5 \mathrm{~g} \mathrm{Ca} / \mathrm{kg} \mathrm{DM}$;

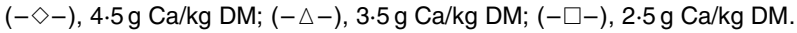

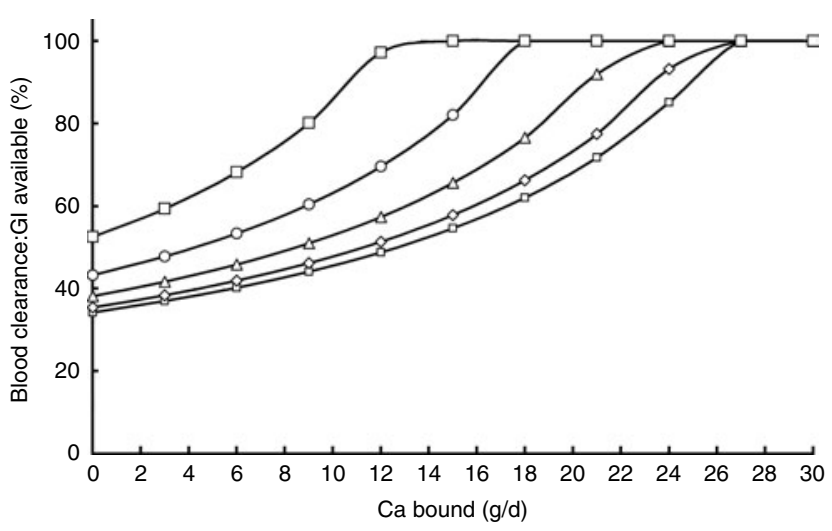

Fig. 5. Predicted effect of calcium binding on the fraction of gastrointestinally (GI) available calcium required for physiological purposes at different levels of dietary calcium: (- - - ), $6.5 \mathrm{~g} \mathrm{Ca} / \mathrm{kg} \mathrm{DM} ;(-\diamond-), 5.5 \mathrm{~g} \mathrm{Ca} / \mathrm{kg} \mathrm{DM}$; $(-\triangle-), 4.5 \mathrm{~g} \mathrm{Ca} / \mathrm{kg} \mathrm{DM}$; (-O-), $3.5 \mathrm{~g} \mathrm{Ca} / \mathrm{kg} \mathrm{DM}$; (- -$), 2.5 \mathrm{~g} \mathrm{Ca} / \mathrm{kg} \mathrm{DM}$.

preventive effect of high levels of dietary $\mathrm{Ca}$; however, the mode of action is most probably explained by the sufficient paracellular intestinal absorption that compensates for Ca clearance at calving.

The model proposed here can be used to quantify the amount of $\mathrm{Ca}$ that must be made unavailable with a dietary binding agent, such as a zeolite clay or phytic acid, to induce the adaptation of $\mathrm{Ca}$ metabolism (Fig. 5). Obviously, higher dietary Ca levels require greater gastrointestinal precipitation to induce this adaptation. The model shows that the preventive efficiency of precipitation decreases at high dietary $\mathrm{Ca}$ intake. At intakes of $2.5 \mathrm{~g} / \mathrm{kg}$ DM, precipitating $15 \%$ of the intake could be sufficient, while at intakes of $5.5 \mathrm{~g} / \mathrm{kg} \mathrm{DM}$, as much as $25 \%$ of dietary Ca would have to be precipitated.

\section{Conclusions}

Milk fever is a disease specific to dairy cattle that is caused by the disparity between the great milk yield potential after calving and the small $\mathrm{Ca}$ requirements in late gestation. Milk fever has a clear and direct impact on animal welfare, but its importance is largely found in its indirect effects on early lactation health and its high economic impact on dairy production.

Ca homeostasis is a robust system controlled by metabolic adaptations that take place in the kidney, the gastrointestinal epithelium and bone. Modulation of renal reabsorption occurs rapidly, controlling small negative or large positive Ca fluctuations. The adaptation of gastrointestinal absorption represents an effective mechanism to compensate for hypocalcaemia. When this mechanism is insufficient, bone mobilisation is utilised. These last two adaptations involve processes of cell differentiation that involve a delay of 1 or $2 \mathrm{~d}$. Our model shows that the delay in gastrointestinal adaptation might be the underlying cause of the failure of dairy cows to cope with the sudden change in the rate of $\mathrm{Ca}$ clearance at calving, which results in transient hypocalcaemia. 
The model quantitatively illustrates the effects of different diets and metabolic states before calving on the early activation of gastrointestinal absorption. Heifers present an up-regulated Ca metabolism before calving because of the $\mathrm{Ca}$ requirements for growth, causing them to be less susceptible to milk fever. Limiting the dietary Ca availability quantitatively or qualitatively induces a similar metabolic adaptation. Inducing metabolic acidosis prevents the renal reabsorption of $\mathrm{Ca}$, thereby inducing hypercalciuria, which challenges the homeostatic system and up-regulates $\mathrm{Ca}$ metabolism. The induction of a metabolic adaptation before calving seems to be the mode of action of the currently proposed strategies for the dietary prevention of periparturient hypocalcaemia.

\section{Acknowledgements}

The present review was written within a project on milk fever prevention funded by Nutreco, a company that markets animal nutrition products and services.

J. M.-T. wrote the basic manuscript upon which this review was built and M. W. A. V. provided contributions and reviews.

J. M.-T. is an employee of Nutreco Research and Development. M. W. A. V. has no conflicts of interest.

\section{References}

1. Ramberg C, Johnson E, Fargo R, et al. (1984) Calcium homeostasis in cows, with special reference to parturient hypocalcemia. Am J Physiol Regul Integr Comp Physiol 246, 698-704.

2. Diamond J (2002) Evolution, consequences and future of plant and animal domestication. Nature 418, 700-707.

3. Hare E, Norman H \& Wright J (2006) Survival rates and productive herd life of dairy cattle in the United States. J Dairy Sci 89, 3713-3720.

4. Reksen O, Tverdal A \& Ropstad E (1999) A comparative study of reproductive performance in organic and conventional dairy husbandry. J Dairy Sci 82, 2605-2610.

5. Weigel K, Palmer R \& Caraviello D (2003) Investigation of factors affecting voluntary and involuntary culling in expanding dairy herds in Wisconsin using survival analysis. J Dairy Sci 86, 1482-1486.

6. Fleischer P, Metzner M, Beyerbach M, et al. (2001) The relationship between milk yield and the incidence of some diseases in dairy cows. J Dairy Sci 84, 2025-2035.

7. Heringstad B, Klemetsdal G \& Steine T (2007) Selection responses for disease resistance in two selection experiments with Norwegian red cows. J Dairy Sci 90, 2419-2426.

8. Grohn Y, Eicker S, Ducrocq V, et al. (1998) Effect of diseases on the culling of Holstein dairy cows in New York State. J Dairy Sci 81, 966-978.

9. Darwin C (1859) On the Origin of Species by Means of Natural Selection or the Preservation of Favoured Races in the Struggle for Life. London: J. Murray.

10. Ingvartsen KL (2006) Feeding-and management-related diseases in the transition cow: physiological adaptations around calving and strategies to reduce feeding-related diseases. Anim Feed Sci Technol 126, 175-213.
11. DeGaris P \& Lean I (2008) Milk fever in dairy cows: a review of pathophysiology and control principles. Vet $J$ 176, 58-69.

12. Gallo L, Carnier P, Cassandro M, et al. (1996) Change in body condition score of Holstein cows as affected by parity and mature equivalent milk yield. J Dairy Sci 79, 1009-1015.

13. Bauman DE \& Bruce Currie W (1980) Partitioning of nutrients during pregnancy and lactation: a review of mechanisms involving homeostasis and homeorhesis. J Dairy Sci 63, 1514-1529.

14. Barja G (2002) Rate of generation of oxidative stress-related damage and animal longevity. Free Radical Biol Med 33, $1167-1172$.

15. Tamminga S (2003) Pollution due to nutrient losses and its control in European animal production. Livest Prod Sci 84, $101-111$

16. Reinhardt TA, Lippolis JD, McCluskey BJ, et al. (2011) Prevalence of subclinical hypocalcemia in dairy herds. Vet J 188, 122-124.

17. Roche J \& Berry D (2006) Periparturient climatic, animal, and management factors influencing the incidence of milk fever in grazing systems. J Dairy Sci 89, 2775-2783.

18. Case RM, Eisner D, Gurney A, et al. (2007) Evolution of calcium homeostasis: from birth of the first cell to an omnipresent signalling system. Cell Calcium 42, 345-350.

19. Breves G, Schröder B \& Muscher A (2010) Luminal and endocrine factors for regulation of intestinal monosaccharide and $\mathrm{Ca}^{2+}$ transport. Livest Prod Sci 134, 4-10.

20. Goff J (2006) Macromineral physiology and application to the feeding of the dairy cow for prevention of milk fever and other periparturient mineral disorders. Anim Feed Sci Technol 126, 237-257.

21. Horst R (1986) Regulation of calcium and phosphorus homeostasis in the dairy cow. J Dairy Sci 69, 604-616.

22. Schröder B \& Breves G (2007) Mechanisms and regulation of calcium absorption from the gastrointestinal tract in pigs and ruminants: comparative aspects with special emphasis on hypocalcemia in dairy cows. Anim Health Res Rev 7, 31-41.

23. Schröder B, Rittmann I, Pfeffer E, et al. (1997) In vitro studies on calcium absorption from the gastrointestinal tract in small ruminants. J Comp Physiol B 167, 43-51.

24. Wilkens MR, Kunert-Keil C, Brinkmeier H, et al. (2009) Expression of calcium channel TRPV6 in ovine epithelial tissue. Vet J 182, 294-300.

25. Wilkens MR, Mrochen N, Breves G, et al. (2011) Gastrointestinal calcium absorption in sheep is mostly insensitive to an alimentary induced challenge of calcium homeostasis. Comp Biochem Physiol B Biochem Mol Biol 158, 199-207.

26. Sidler-Lauff K, Boos A, Kraenzlin M, et al. (2010) Influence of different calcium supplies and a single vitamin D injection on vitamin $\mathrm{D}$ receptor and calbindin $\mathrm{D}_{9 \mathrm{k}}$ immunoreactivities in the gastrointestinal tract of goat kids. J Anim Sci 88, 3598-3610.

27. Suzuki Y, Landowski C \& Hediger M (2008) Mechanisms and regulation of epithelial $\mathrm{Ca}^{2+}$ absorption in health and disease. Annu Rev Physiol 70, 257-271.

28. Brown EM, Gamba G, Riccardi D, et al. (1993) Cloning and characterization of an extracellular $\mathrm{Ca}^{2+}$-sensing receptor from bovine parathyroid. Nature 366, 575-580.

29. Martín-Tereso J, Derks M, van Laar H, et al. (2010) Urinary calcium excretion in non-lactating dairy cows in relation to intake of fat-coated rice bran. J Anim Physiol Anim Nutr (Berl) 94, 129-136.

30. Schonewille J, Van't Klooster A, Wouterse H, et al. (1999) Hypocalcemia induced by intravenous administration of 
disodium ethylenediaminotetraacetate and its effects on excretion of calcium in urine of cows fed a high chloride diet. J Dairy Sci 82, 1317-1324.

31. Armbrecht HJ, Boltz MA, Christakos S, et al. (1998) Capacity of 1,25-dihydroxyvitamin $\mathrm{D}$ to stimulate expression of calbindin D changes with age in the rat. Arch Biochem Biophys 352, 159-164.

32. Martín-Tereso J, van Puijenbroek R, van Laar H, et al. (2011) Effect of feeding rumen protected rice bran on calcium homeostasis of non-lactating multiparous cows. J Anim Physiol Anim Nutr (Berl) 95, 236-244.

33. Taylor M, Knowlton K, McGilliard M, et al. (2008) Blood mineral, hormone, and osteocalcin responses of multiparous Jersey cows to an oral dose of 25-hydroxyvitamin $\mathrm{D}_{3}$ or vitamin $\mathrm{D}_{3}$ before parturition. J Dairy Sci 91, 2408-2416.

34. Liesegang A, Eicher R, Sassi ML, et al. (2000) The course of selected bone resorption marker concentrations in response to short term hypocalcemia experimentally induced with disodium EDTA infusions in dairy cows. $J$ Vet Med A 47, 477-487.

35. Erben R (2001) Vitamin D analogs and bone. J Musculoskelet Neuronal Interact 2, 59-69.

36. Ferraris R \& Diamond J (1989) Specific regulation of intestinal nutrient transporters by their dietary substrates. Annu Rev Physiol 51, 125-141.

37. Hoenderop JGJ, Nilius B \& Bindels RJM (2005) Calcium absorption across epithelia. Physiol Rev 85, 373-422.

38. Liesegang A, Singer K \& Boos A (2008) Vitamin D receptor amounts across different segments of the gastrointestinal tract in Brown Swiss and Holstein Frisean cows of different age. J Anim Physiol Anim Nutr (Berl) 92, 316-323.

39. Yamagishi N, Yukawa $\mathrm{Y}$, Ishiguro $\mathrm{N}$, et al. (2002) Expression of calbindin $\mathrm{D}_{9 \mathrm{k}}$ messenger ribonucleic acid in the gastrointestinal tract of dairy cattle. $J$ Vet Med A 49, 461-465.

40. Pérez A, Picotto G, Carpentieri A, et al. (2008) Minireview on regulation of intestinal calcium absorption. Emphasis on molecular mechanisms of transcellular pathway. Digestion 77, 22-34.

41. Wasserman R (2004) Vitamin D and the dual processes of intestinal calcium absorption. J Nutr 134, 3137-3139.

42. Bouillon R, Van Cromphaut S \& Carmeliet G (2003) Intestinal calcium absorption: molecular vitamin $\mathrm{D}$ mediated mechanisms. J Cell Biochem 88, 332-339.

43. Nilius B, Prenen J, Hoenderop J, et al. (2002) Fast and slow inactivation kinetics of the $\mathrm{Ca}^{2+}$ channels ECaC1 and ECaC2 (TRPV5 and TRPV6). Role of the intracellular loop located between transmembrane segments 2 and 3. J Biol Chem 277, 30852-30858.

44. Bronner F (2003) Mechanisms of intestinal calcium absorption. J Cell Biochem 88, 383-393.

45. Khanal R \& Nemere I (2008) Regulation of intestinal calcium transport. Annu Rev Nutr 28, 179-196.

46. Schröder B, Goebel W, Huber K, et al. (2001) No effect of vitamin $\mathrm{D}_{3}$ treatment on active calcium absorption across ruminal epithelium of sheep. J Vet Med A Physiol Pathol Clin Med 48, 353-363.

47. Ajibade D, Benn BS \& Christakos S (1998) Mechanism of action of 1,25-dihydroxyvitamin $\mathrm{D}_{3}$ on intestinal calcium absorption and renal alcium transport. In Vitamin $D$ : Molecular Biology, and Clinical Applications, 2nd ed., pp. 175-187 [MF Holick, editor]. New York: Humana Press.

48. Schonewille JT, Van't Klooster AT, Dirkzwager A, et al. (1994) Stimulatory effect of an anion(chloride)-rich ration on apparent calcium absorption in dairy cows. Livest Prod Sci 40, 233-240.
49. Roche J, Dalley D, Moate P, et al. (2003) Dietary cationanion difference and the health and production of pasture-fed dairy cows 2. Nonlactating periparturient cows. J Dairy Sci 86, 979-987.

50. Hoenderop $\mathrm{J}$, van Leeuwen $\mathrm{J}$, van der Eerden $\mathrm{B}$, et al (2003) Renal Ca 2 wasting, hyperabsorption, and reduced bone thickness in mice lacking TRPV5. J Clin Invest $\mathbf{1 1 2}$ 1906-1914.

51. Horst R, Goff J \& Reinhardt T (1994) Calcium and vitamin D metabolism in the dairy cow. J Dairy Sci 77, 1936-1951.

52. Norman A, Friedlander E \& Henry H (1981) Determination of the rates of synthesis and degradation of vitamin D-dependent chick intestinal and renal calcium-binding proteins. Arch Biochem Biophys 206, 305-317.

53. Creamer B, Shorter R \& Bamforth J (1961) The turnover and shedding of epithelial cells. Gut 2, 110-116.

54. Vogetseder A, Karadeniz A, Kaissling B, et al. (2005) Tubular cell proliferation in the healthy rat kidney. Histochem Cell Biol 124, 97-104.

55. Walters J \& Weiser M (1987) Calcium transport by rat duodenal villus and crypt basolateral membranes. Am J Physiol Gastrointest Liver Physiol 252, 170-177.

56. Halloran BP \& De Luca HF (1981) Intestinal calcium transport: evidence for two distinct mechanisms of action of 1,25-dihydroxyvitamin $\mathrm{D}_{3}$. Arch Biochem Biophys 208 , 477-486.

57. Kumar R (1986) The metabolism and mechanism of action of 1,25-dihydroxyvitamin $\mathrm{D}_{3}$. Kidney Int 30, 793-803.

58. Bikle D, Zolock D \& Munson S (1984) Differential response of duodenal epithelial cells to 1,25-dihydroxyvitamin $\mathrm{D}_{3}$ according to position on the villus: a comparison of calcium uptake, calcium-binding protein, and alkaline phosphatase activity. Endocrinology 115, 2077-2084.

59. Centeno V, Díaz de Barboza G, Marchionatti A, et al. (2004) Dietary calcium deficiency increases $\mathrm{Ca}^{2+}$ uptake and $\mathrm{Ca}^{2+}$ extrusion mechanisms in chick enterocytes. Comp Biochem Physiol 139, 133-141.

60. Smith M (1993) Genetic regulation of enterocyte differentiation. Proc Nutr Soc 52, 293-300.

61. Pivonka P, Zimak J, Smith D, et al. (2008) Model structure and control of bone remodeling: a theoretical study. Bone 43, 249-263.

62. Hadjidakis D \& Androullakis I (2006) Bone remodeling. Ann N Y Acad Sci 1092, 385-396.

63. Parfitt A (1976) The actions of parathyroid hormone on bone. Relation to bone remodelling and turnover, calcium homeostasis, and metabolic bone disease. Part II. Metabolism 25, 909-955.

64. Lemaire V, Tobin F, Greller L, et al. (2004) Modeling the interactions between osteoblast and osteoclast activities in bone remodeling. J Theor Biol 229, 293-309.

65. Bieglmayer C, Prager G \& Niederle B (2002) Kinetic analyses of parathyroid hormone clearance as measured by three rapid immunoassays during parathyroidectomy. Clin Chem 48, 1731-1738.

66. Martin T \& Udagawa N (1998) Hormonal regulation of osteoclast function. Trends Endocrinol Metab 9, 6-12.

67. Greenfield E, Bi Y \& Miyauchi A (1999) Regulation of osteoclast activity. Life Sci 65, 1087-1102.

68. Goff J, Littledike E \& Horst R (1986) Effect of synthetic bovine parathyroid hormone in dairy cows: prevention of hypocalcemic parturient paresis. J Dairy Sci 69, 2278-2289.

69. Littledike $\mathrm{E} \&$ Horst $\mathrm{R}(1982)$ Vitamin $\mathrm{D}_{3}$ toxicity in dairy cows. J Dairy Sci 65, 749-759.

70. Horst RL, Goff JP, Reinhardt TA, et al. (1997) Strategies for preventing milk fever in dairy cattle. J Dairy Sci $\mathbf{8 0}$, $1269-1280$ 
71. Boda J \& Cole H (1956) Calcium metabolism with special reference to parturient paresis (milk fever) in dairy cattle: a review. J Dairy Sci 39, 1027-1054.

72. Thilsing-Hansen T, Jørgensen R \& Østergaard S (2002) Milk fever control principles: a review. Acta Vet Scand 43, $1-19$.

73. Hibbs J \& Conrad H (1960) Studies of milk fever in dairy cows. VI. Effect of three prepartal dosage levels of vitamin D on milk fever incidence. J Dairy Sci $\mathbf{4 3}$, 1124-1129.

74. Hodnett DW, Jorgensen NA \& Deluca HF (1992) $1 \alpha$-Hydroxyvitamin $\mathrm{D}_{3}$ plus 25 -hydroxyvitamin $\mathrm{D}_{3}$ reduces parturient paresis in dairy cows fed high dietary calcium. J Dairy Sci 75, 485-491.

75. Goff JP, Horst RL, Littledike ET, et al. (1986) Bone resorption, renal function and mineral status in cows treated with 1,25-dihydroxycholecalciferol and its 24-fluoro analogues. $J$ Nutr 116, 1500-1510.

76. Gast D, Horst R, Jorgensen N, et al. (1979) Potential use of 1,25-dihydroxycholecalciferol for prevention of parturient paresis. J Dairy Sci 62, 1009-1013.

77. Horst R, Goff J \& Reinhardt T (2003) Role of vitamin D in calcium homeostasis and its use in prevention of bovine periparturient paresis. Acta Vet Scand Suppl 97, 35-50.

78. Hove K, Horst R \& Littledike E (1983) Effects of $1 \alpha$-hydroxyvitamin $\mathrm{D}_{3}, 1,25$-dihydroxyvitamin $\mathrm{D}_{3}, 1,24,25$-trihydroxyvitamin $D_{3}$, and 1,25,26-trihydroxyvitamin $D_{3}$ on mineral metabolism and 1,25-dihydroxyvitamin $\mathrm{D}$ concentrations in dairy cows. J Dairy Sci 66, 59-66.

79. Goings R, Jacobson N, Beitz D, et al. (1974) Prevention of parturient paresis by a prepartum, calcium-deficient diet. J Dairy Sci 57, 1184-1188.

80. Wiggers K, Nelson D \& Jacobson N (1975) Prevention of parturient paresis by a low-calcium diet prepartum: a field study. J Dairy Sci 58, 430-431.

81. Yarrington J, Capen C, Black H, et al. (1977) Effects of a low calcium prepartal diet on calcium homeostatic mechanisms in the cow: morphologic and biochemical studies. $J$ Nutr 107, 2244-2256.

82. Green H, Horst R, Beitz D, et al. (1981) Vitamin D metabolites in plasma of cows fed a prepartum low-calcium diet for prevention of parturient hypocalcemia. J Dairy Sci 64, 217-226.

83. Kichura T, Horst R, Beitz D, et al. (1982) Relationships between prepartal dietary calcium and phosphorus, vitamin D metabolism, and parturient paresis in dairy cows. J Nutr 112, 480-487.

84. Shappell N, Herbein J, Deftos L, et al. (1987) Effects of dietary calcium and age on parathyroid hormone, calcitonin and serum and milk minerals in the periparturient dairy cow. J Nutr 117, 201-207.

85. Oetzel G (1991) Meta-analysis of nutritional risk factors for milk fever in dairy cattle. J Dairy Sci 74, 3900-3912.

86. Lean I, DeGaris P, McNeil D, et al. (2006) Hypocalcemia in dairy cows: meta-analysis and dietary cation anion difference theory revisited. J Dairy Sci 89, 669-684.

87. Roche J, Dalley D \& O'Mara F (2007) Effect of a metabolically created systemic acidosis on calcium homeostasis and the diurnal variation in urine $\mathrm{pH}$ in the non-lactating pregnant dairy cow. J Dairy Res $\mathbf{7 4}, 34-39$.

88. Moore S, VandeHaar M, Sharma B, et al. (2000) Effects of altering dietary cation-anion difference on calcium and energy metabolism in peripartum cows. $J$ Dairy Sci 83, 2095-2104.

89. Goff J \& Horst R (1997) Effects of the addition of potassium or sodium, but not calcium, to prepartum rations on milk fever in dairy cows. J Dairy Sci 80, 176-186.
90. Block E (1984) Manipulating dietary anions and cations for prepartum dairy cows to reduce incidence of milk fever. J Dairy Sci 67, 2939-2948.

91. Charbonneau E, Pellerin D \& Oetzel G (2006) Impact of lowering dietary cation-anion difference in nonlactating dairy cows: a meta-analysis. J Dairy Sci 89, 537-548.

92. Goff J, Horst R, Mueller F, et al. (1991) Addition of chloride to a prepartal diet high in cations increases 1,25-dihydroxyvitamin D response to hypocalcemia preventing milk fever. J Dairy Sci 74, 3863-3871.

93. Goff $\mathrm{J}$ (2008) The monitoring, prevention, and treatment of milk fever and subclinical hypocalcemia in dairy cows. Vet J 176, 50-57.

94. Hu W \& Murphy M (2004) Dietary cation-anion difference effects on performance and acid-base status of lactating dairy cows: a meta-analysis. J Dairy Sci 87, 2222-2229.

95. Thilsing-Hansen T, Jorgensen R, Enemark J, et al. (2002) The effect of zeolite A supplementation in the dry period on periparturient calcium, phosphorus, and magnesium homeostasis. J Dairy Sci 85, 1855-1862.

96. Enemark J, Frandsen A, Thilsing-Hansen T, et al. (2003) Aspects of physiological effects of sodium zeolite A supplementation in dry, non-pregnant dairy cows fed grass silage. Acta Vet Scand Suppl 97, 97-117.

97. Enemark J, Kirketerp-Møller C \& Jørgensen R (2003) Effect of prepartum zeolite A supplementation on renal calcium excretion in dairy cows around calving and evaluation of a field test kit for monitoring it. Acta Vet Scand Suppl 97, $119-136$

98. Thilsing-Hansen T, Jørgensen R, Enemark J, et al. (2003) The effect of zeolite A supplementation in the dry period on blood mineral status around calving. Acta Vet Scand Suppl 97, 87-95.

99. Katsoulos P, Roubies N, Panousis N, et al. (2005) Effects of long-term dietary supplementation with clinoptilolite on incidence of parturient paresis and serum concentrations of total calcium, phosphate, magnesium, potassium, and sodium in dairy cows. Am J Vet Res 66, 2081-2085.

100. Thilsing T, Larsen T, Jorgensen R, et al. (2007) The effect of dietary calcium and phosphorus supplementation in zeolite A treated dry cows on periparturient calcium and phosphorus homeostasis. J Vet Med A 54, 82-91.

101. Grabherr H, Spolders M, Flachowsky G, et al. (2008) Influence of zeolite A supplementation during the dry period of dairy cows on feed intake, on the macro and trace element metabolism around calving and milk yield in the following lactation. Berl Munch Tierarztl Wochenschr 121, 41-52.

102. Grabherr H, Spolders M, Furll M, et al. (2009) Effect of several doses of zeolite A on feed intake, energy metabolism and on mineral metabolism in dairy cows around calving. J Anim Physiol Anim Nutr (Berl) 93, 221-236.

103. Pallesen A, Pallesen F, Jørgensen R, et al. (2008) Effect of pre-calving zeolite, magnesium and phosphorus supplementation on periparturient serum mineral concentrations. Vet J 175, 234-239.

104. Wilson G (2001) A novel nutritional strategy to prevent milk fever and stimulate milk production in dairy cows. $N Z$ Vet $J$ 49, 78-80.

105. Wilson G (2003) Development of a novel concept (Calcigard) for activation of calcium absorption capacity and prevention of milk fever. Acta Vet Scand Suppl 97, 77-82.

106. Palmquist D, Jenkins T \& Joyner A Jr (1986) Effect of dietary fat and calcium source on insoluble soap formation in the rumen. J Dairy Sci 69, 1020-1025.

107. Doreau M \& Ferlay A (1994) Digestion and utilisation of fatty acids by ruminants. Anim Feed Sci Technol 45, $379-396$. 
108. Douglas G, Overton T, Bateman H, et al. (2004) Peripartal metabolism and production of Holstein cows fed diets supplemented with fat during the dry period. J Dairy Sci 87, 4210-4220.

109. Ohkawa T, Ebisuno S, Kitagawa M, et al. (1984) Rice bran treatment for patients with hypercalciuric stones: experimental and clinical studies. J Urol 132, 1140-1145.

110. Ebisuno S, Morimoto S, Yasukawa S, et al. (1991) Results of long-term rice bran treatment on stone recurrence in hypercalciuric patients. Br J Urol 67, 237-240.

111. Siener R, Heynck H \& Hesse A (2001) Calcium-binding capacities of different brans under simulated gastrointestinal $\mathrm{pH}$ conditions. In vitro study with ${ }^{45} \mathrm{Ca}$. J Agric Food Chem 49, 4397-4401.

112. Clark W Jr, Wohlt J, Gilbreath R, et al. (1986) Phytate phosphorus intake and disappearance in the gastrointestinal tract of high producing dairy cows. J Dairy Sci 69, 3151-3155.

113. Park W-Y, Matsui T, Konishi C, et al. (1999) Formaldehyde treatment suppresses ruminal degradation of phytate in soyabean meal and rapeseed meal. Br J Nutr 81, 467-471.

114. Bravo D, Meschy F, Bogaert C, et al. (2002) Effects of fungal phytase addition, formaldehyde treatment and dietary concentrate content on ruminal phosphorus availability. Anim Feed Sci Technol 99, 73-95.

115. Konishi C, Matsui T, Park W, et al. (1999) Heat treatment of soybean meal and rapeseed meal suppresses rumen degradation of phytate phosphorus in sheep. Anim Feed Sci Technol 80, 115-122.

116. Martín-Tereso J, Gonzalez A, Van Laar H, et al. (2009) In situ ruminal degradation of phytic acid in formaldehyde-treated rice bran. Anim Feed Sci Technol 152, 286-297.

117. Martín-Tereso J, Martens H \& Deiner C, et al. (2010) Effect of Rumen Protected Rice Bran on Serum Ca of Multiparous Dairy Cows at Calving. 14th international Conference of Production Diseases in Farm Animals, Ghent 2010. Zelzate, Belgium: University Press.

118. Braithwaite GD (1982) Endogenous faecal loss of calcium by ruminants. J Agric Sci $99,355-358$.
119. Lengemann FW (1965) Lack of effect of level of dietary calcium upon fecal endogenous calcium. J Dairy Sci $\mathbf{4 8}$, $1718-1719$.

120. Hansard SL, Crowder H \& Lyke W (1957) The biological availability of calcium in feeds for cattle. J Anim Sci $\mathbf{1 6}$ 437-443.

121. Comar C, Monroe R, Visek W, et al. (1953) Comparison of two isotope methods for determination of endogenous fecal calcium. J Nutr 50, 459-467.

122. Visek W, Monroe R, Swanson E, et al. (1953) Determination of endogenous fecal calcium in cattle by a simple isotope dilution method. J Nutr 50, 23-33.

123. Martz FA, Belo AT, Weiss MF, et al. (1999) True absorption of calcium and phosphorus from corn silage fed to nonlactating, pregnant dairy cows. J Dairy Sci 82, 618-622.

124. Vagnoni D \& Oetzel G (1998) Effects of dietary cationanion difference on the acid-base status of dry cows. J Dairy Sci 81, 1643-1652.

125. Erb RE, Surve AH, Randel RD, et al. (1977) Urinary creatinine as an index of urinary excretion of estrogen in cows prepartum and postpartum. J Dairy Sci 60, 1057-1063.

126. Valadares RFD, Broderick GA, Filho SCV, et al. (1999) Effect of replacing alfalfa silage with high moisture corn on ruminal protein synthesis estimated from excretion of total purine derivatives. J Dairy Sci 82, 2686-2696.

127. Taylor M, Knowlton K, McGilliard M, et al. (2009) Dietary calcium has little effect on mineral balance and bone mineral metabolism through twenty weeks of lactation in Holstein cows. J Dairy Sci 92, 223-237.

128. National Research Council (2001) Nutrient Requirements of Dairy Cattle. Washington, DC: National Academy Press.

129. Horst R, Goff J, Reinhardt T, et al. (1997) Strategies for preventing milk fever in dairy cattle. J Dairy Sci 80, 1269-1280.

130. Martín-Tereso J, Distefano C, van Laar H, et al. (2011) Effect of feeding rumen-protected rice bran on mineral status of non-lactating dairy heifers. J Anim Physiol Anim Nutr (Berl) 95, 73-80. 